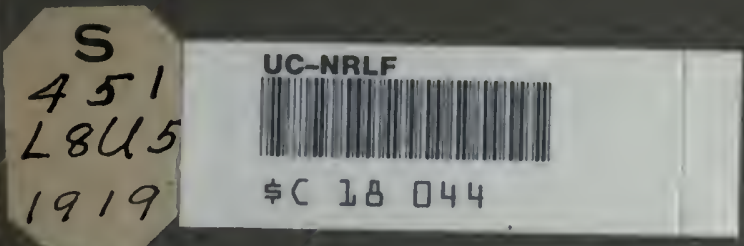

\title{
LOUISINIA
}

United States Railroad Administration, Agricultural Section. 


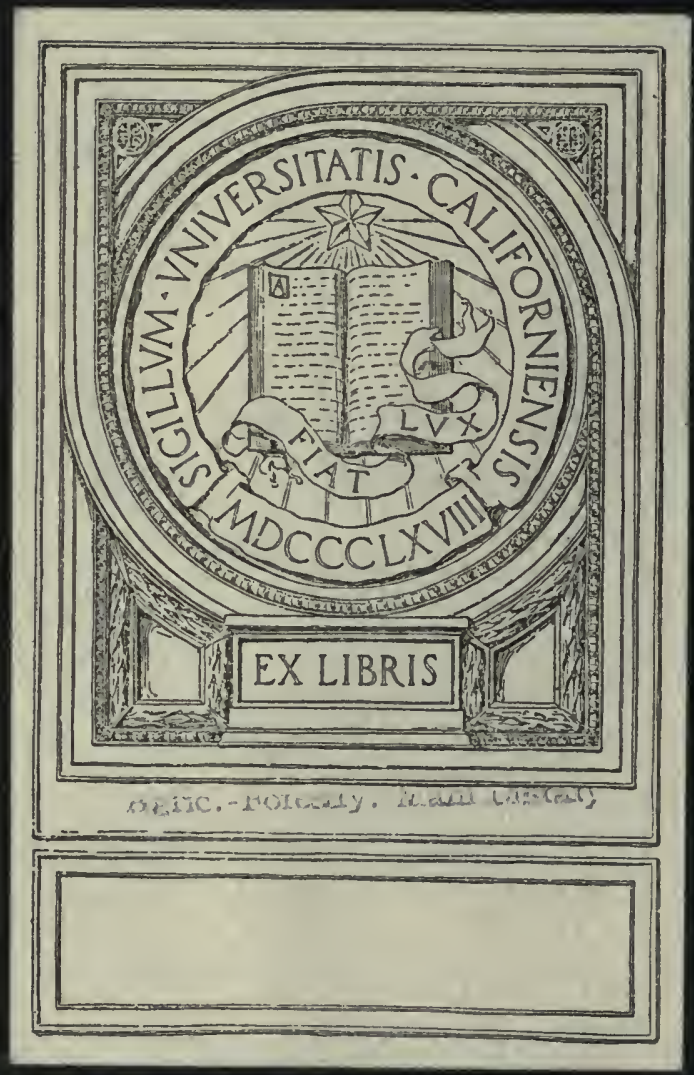



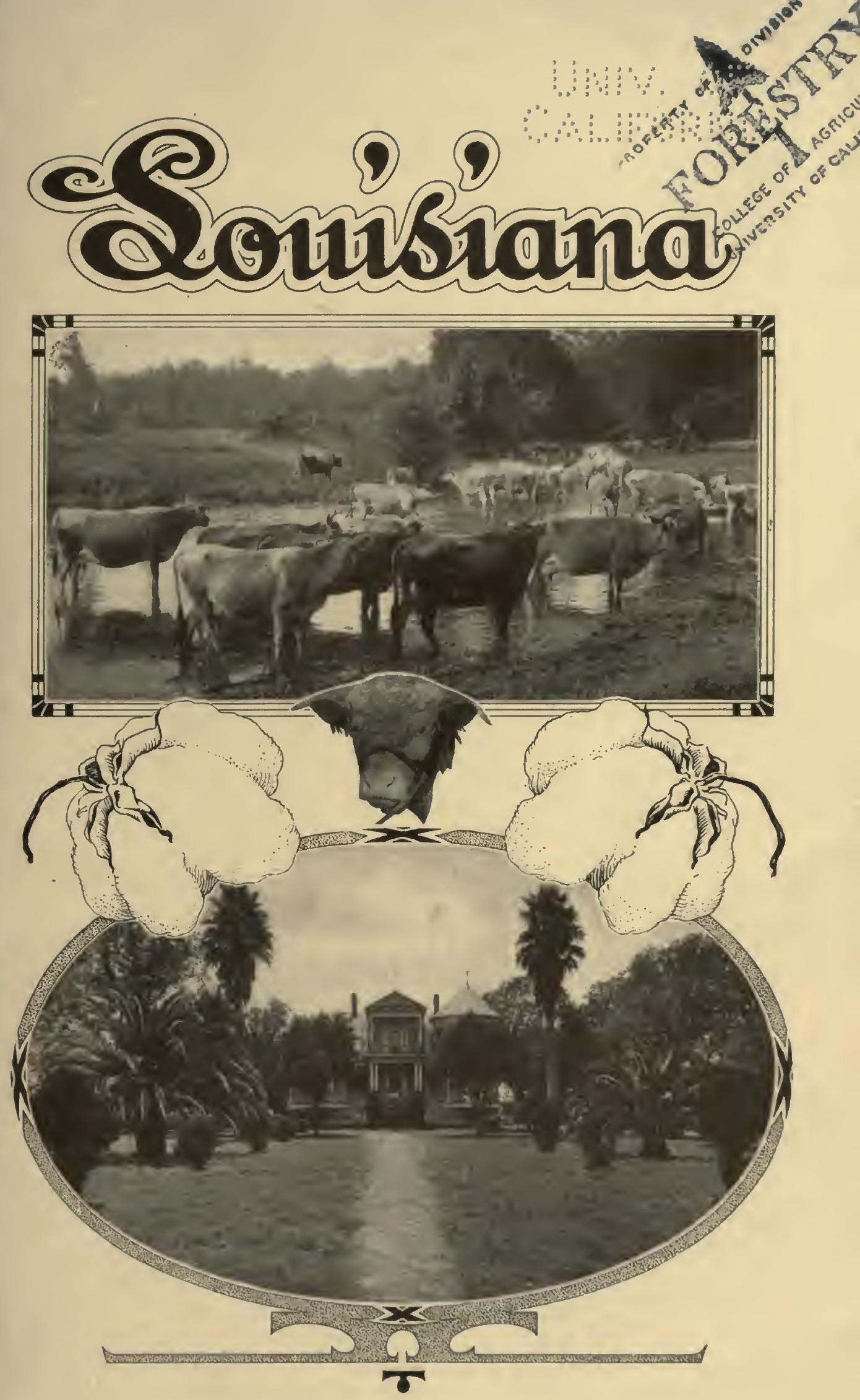


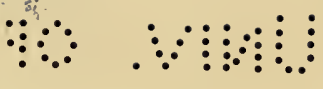

wm

Agric. - Forestry. Main Libra

$$
\begin{aligned}
& 5451 \\
& 4845 \\
& i 919
\end{aligned}
$$




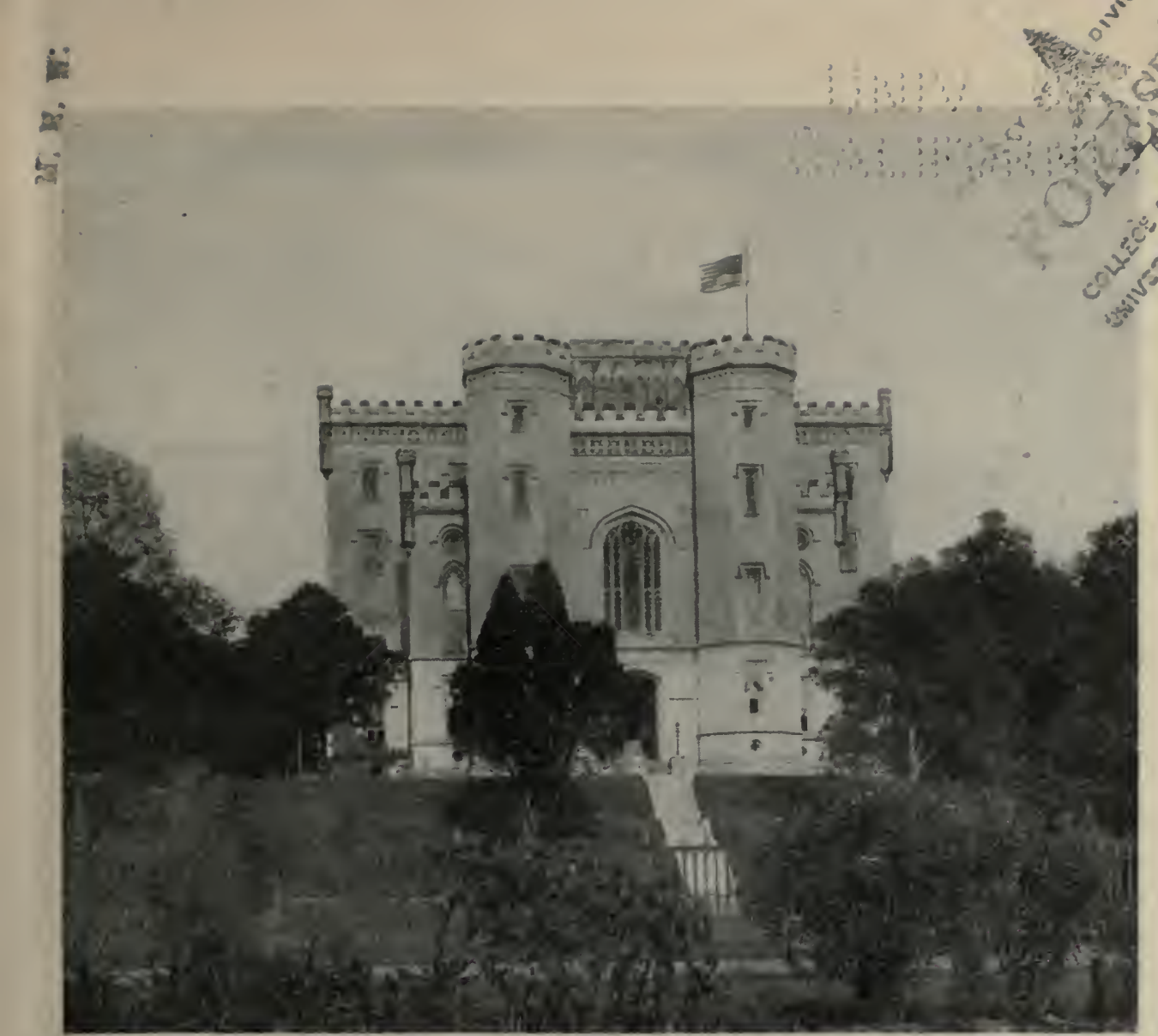

Louisiana State Capitol

\section{Louisiana's Invitation}

L stands for Love of Country

O stands for Opportunity

U stands for Unity

I stands for Independence

S stands for Stability

I stands for Industry

A stands for Advantages

- N stands for Natural Resources

A stands for AGRICULTURE

Of the forty-eight states comprising the United States of America, none has shown a greater love and a greater patriotic spirit for her country than the marvelous Commonwealth of Louisiana, and she bids a most cordial welcome to all who are similarly imbued; to those who seek and are willing to embrace Opportunity; to those who believe in Unity of purpose; to those who seek Inclependence in its broadest sense; to those who believe in Stability and progress; to those who seek a location to engage in any line of Industry; to those who wish to come among us as builders of a Greater Louisiana, she offers her matchless Advantages; to those seeking a location where Natural Resources are unexcelled, and where the richest Agricultural lands on this continent may be found, and last, but not least, to all who love the United States of America, revere its institutions, honor its flag, respect its name, rejoice in its proud history, in its unsullied Liberty, in its glorious past and the promise of its future, this marvelous Empire of the South and the Gateway of Trade for the Mississippi Valley extends a most cordial and generous invitation. 


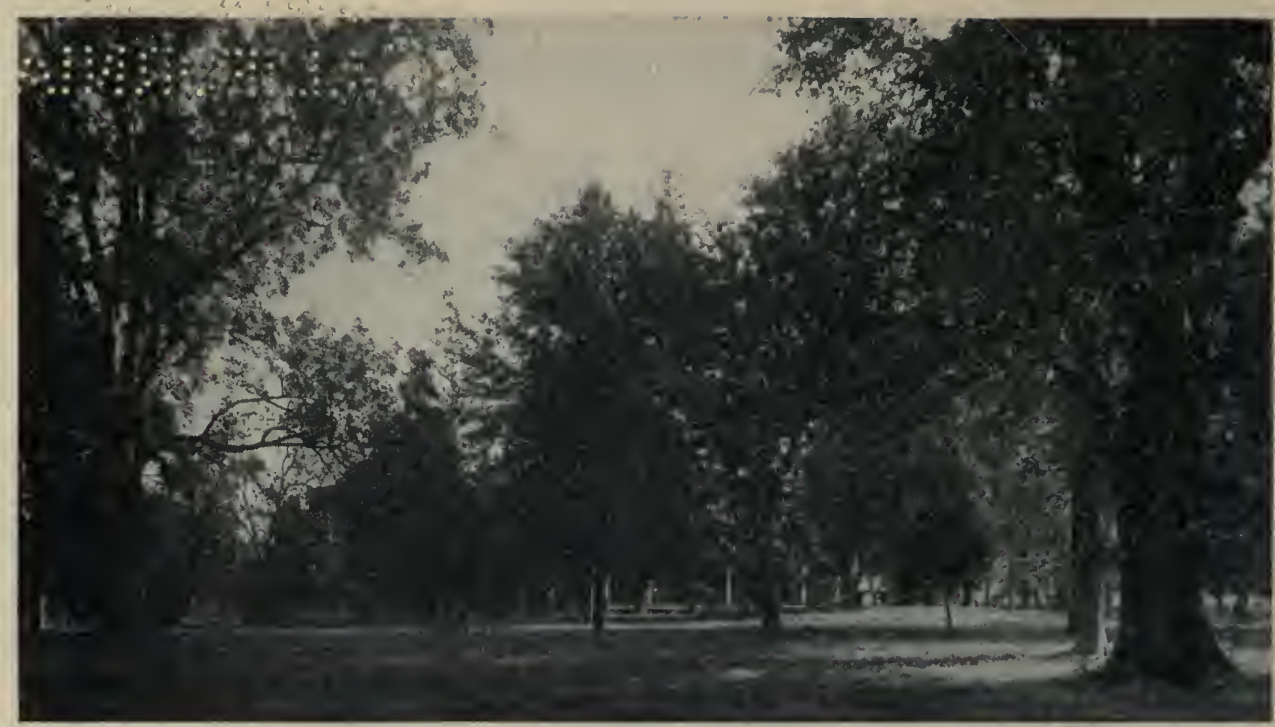

Attractive Surroundings of a Plantation Home

\section{DESGRIPTION AND GENERAL TOPOGRAPHY}

It will be noticed by a glance at the map of Louisiana that the State is intersected by numerous rivers. The Mississippi River forms the eastern border down as far as the mouth of the Red River, and then runs diagonally through that portion of the State lying south of the State of Mississippi. The Red River cuts diagonally through the State from northwest to southeast; the Atchafalaya River, flowing south from where the Red River enters the Mississippi, divides the southern part of the State into the eastern alluvial delta section and the western prairie section. The Sabine River separates it from Texas on the west. The Ouachita River separates the alluvial bottoms of the Mississippi in the northeastern part of the State from the upland pine area between it and the Red River; and numerous smaller rivers, bayous and canals traversing other parts of the State, added to these, give it a total mileage of navigable waterways unequaled by any other state in the Union. There are forty-eight navigable streams, with a total mileage of 4,794 miles.

Reference to a map of the United States will suggest to one at a glance that the State of Louisiana occupies a remarkably advantageous position geographically. It stands at the natural gateway through which must pass the vast tide of commerce, which, originating in the fields, the forests and the mines of thirty states, or nearly half of the total area of the United States, flows seaward in its course to the markets of the world.

The total land area of the State amounts to 45,400 square miles, of which nearly 15,000 square miles, or one-third of the total area, is alluvial soil or "made land," brought down by the flood waters of the Mississippi River in centuries past from the fertile lands of the $1,238,000$ square miles of territory comprising the Mississippi Basin.

In addition to that portion of the State comprising the Valley of the Mississippi there are about 3,000 square miles of exceedingly rich bottom lands of the other rivers that flow through the State, and about 1,500 square miles of level coast marsh land lying between the Atchafalaya River and the western border of the State and adjacent to the Gulf of Mexico.

Next to these lands in point of fertility are the open, rolling, high prairie lands in the southwestern part of the State, known as the Atakapas Prairies, where rice is grown to such a large extent and with such wonderful success.

The bluff or hill lands are located partly in the northeastern part of the State, just west of the alluvial portion, and designated as the Bayou Macon Hills, and partly in that portion of the State lying east of the Mississippi River, immediately south of the Mississippi State line and north of the city of Baton Rouge. 
Perhaps the largest undeveloped area is the upland or mixed hardwood and pine hill country, which is located in the northern and northwestern part of the State.

The long-leaf pine hill lands constitute a large area in the central and western part of the State on both sides of the Red River, and also a small area northeast from New Orleans.

Finally there are the long-leaf pine flats, part of which are located in the southwestern section of the State adjoining the prairie region and part east of the Mississippi River, north of Lake Pontchartrain.

\section{ALLUVIAL DELTA LANDS}

The Alluvial Delta Lands of Louisiana occupy an area of about 8,000 square miles located in the southeast corner of the State, where the Mississippi River enters the Gulf of Mexico. They lie east of a line drawn south of the mouth of the Red River, and south of a line drawn east and west along the north shore of Lake Pontchartrain. The entire region might be described as a rectangle about 150 miles east and west by 90 miles north and south, with the Mississippi River running diagonally across it from the northwest corner to the southeast corner, and the city of New Orleans located about twenty-five miles northeast of its geometrical center.

All of the land in this quadrangle to a depth of over 2,000 feet has been formed by deposit from the overflow of the Mississippi River and is, therefore, pure soil of the very richest character; soil that has been washed down from the fields and hillsides of thirty states, whose drainage water finds an outlet to the sea through the mouth of this great river. The process of filling in the Gulf and building up this area by deposit has been going on for centuries, so that the mouth of the river, which at one time must have been near the City of Baton Rouge, has been gradually pushed out into the Gulf, the sediment in the escaping flood waters covering the entire area from Pearl River, on the east, to the Atchafalaya River, on the west, and raising it a little higher each year.

Ninety per cent of the land in this area is virgin soil covered with a swamp growth of cypress and willow in the upper or higher portion of the region, and marsh or open prairie grass in the larger portion nearest the Gulf. The only land available for development and cultivation during the past two hundred years that this region has been inhabitated, consisted of a strip of land two miles wide on either side of the river, following its course for about 140 miles diagonally across the region, a strip of land about three-quarters of a mile wide, bordering both banks of Bayou Lafourche for a distance of seventy-five miles in its course

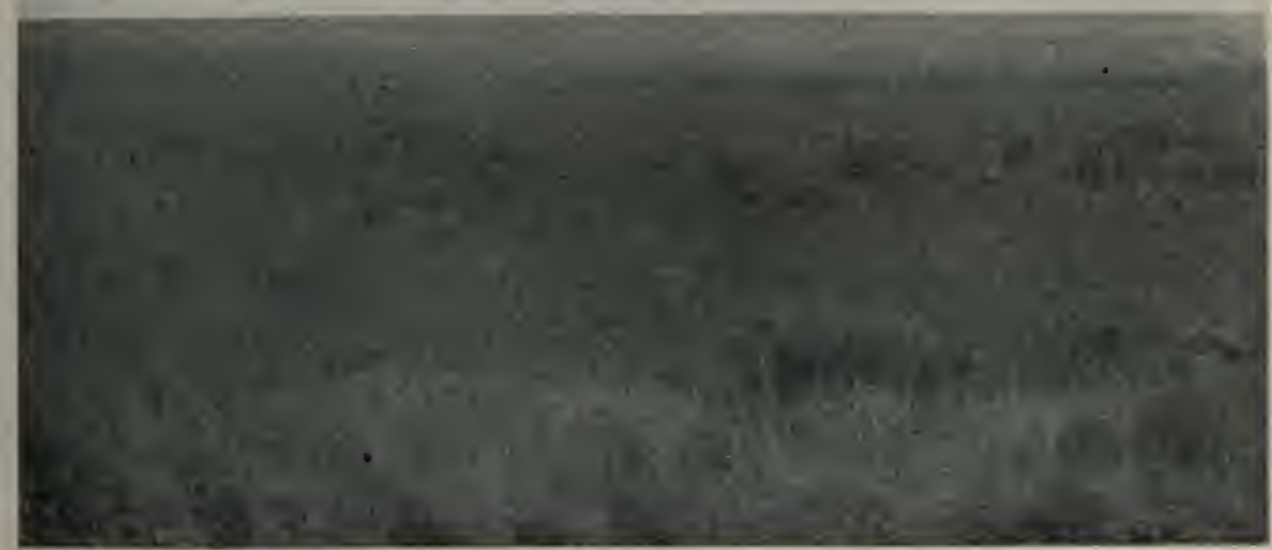

Alluvial Delta Lands before Reclamation 
south from Donaldsonville to the Gulf, and about seventy-five miles of similar strips of high land along Bayou Manchac, Bayou Plaquemine, Bayou Terrebonne, Bayou Black and Bayou Terre aux Boeuf.

In all there are about 500,000 acres embraced in these lands adjacent to the streams that have been raised to a higher elevation than the other lands in the region by reason of their receiving the greater volume of deposit during the process of formation. These high strips of land, being available for cultivation without artificial drainage, were cleared, settled and occupied by the first settlers of Louisiana and for over a hundred years they have been cultivated as the banner sugar plantations.

The one constant menace to all of the alluvial land area of Louisiana was the spring overflow of the Mississippi River. Even after plantations had been established by the early settlers along the higher ridges the flood waters were allowed to inundate the swamps and marshes comprising ninety per cent of the alluvial area. Gradually, however, levees were erected along both banks of the river, completely confining the flood waters to the proper channels, and these confining walls are now so complete and so dependable that there is little danger from overflow and within the past ten years an opportunity has been given to extend the cultivated area in this region by reclamation through artificial drainage.

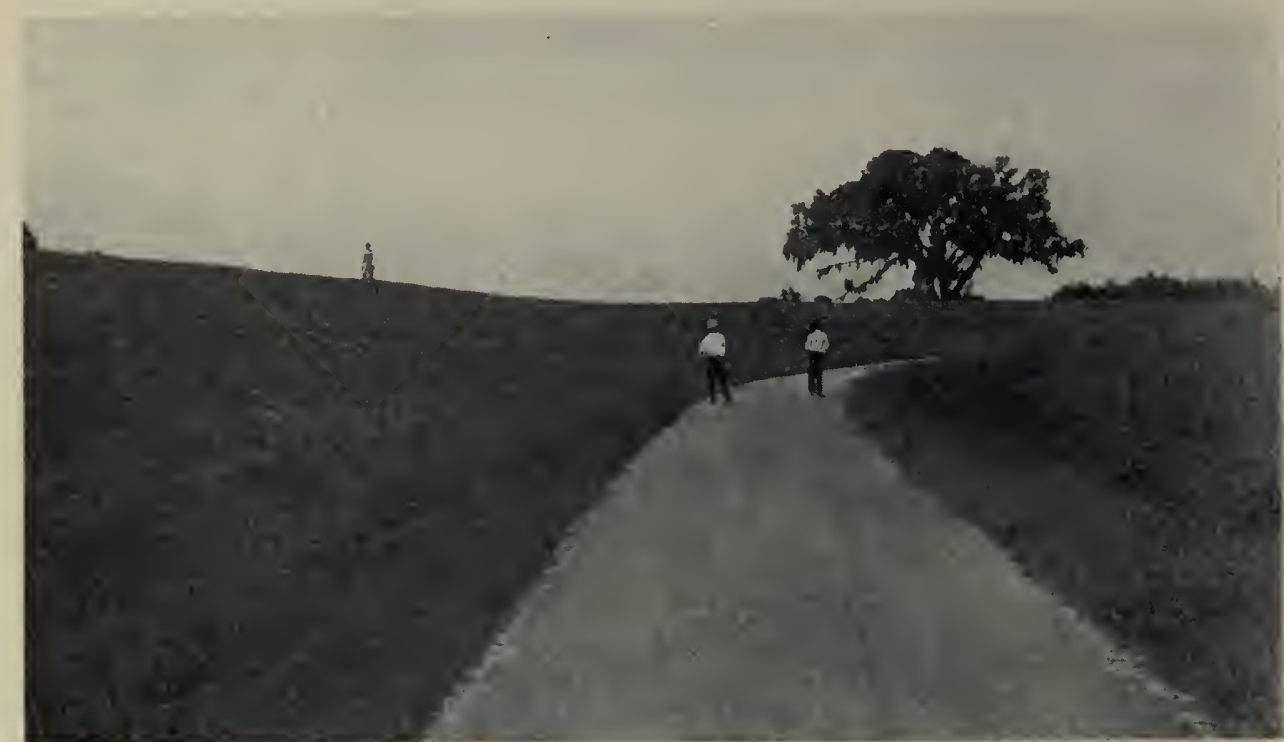

Adequate Levees Insure Protection from Future Floods

Estimating the total area embraced in this alluvial region to be approximately 5,000,000 acres, and allowing 500,000 acres for high ridges now in cultivation, there remain about $4,500,000$ acres to be reclaimed, 2,500,000 acres of which are open marsh prairie lands that require artificial drainage only to enable them to be cultivated and developed at once.

There is no richer soil on the face of the earth, in fact the soil is almost too rich, the first two or three feet nearest the surface consisting almost entirely of decayed vegetable matter, exceedingly rich in nitrogen and, despite the fact that the land has been covered with swamp water ever since its formation, it contains such an abundance of decayed fish and shell matter that no sour or acid effects are observed even during the first year that it is put into cultivation.

These prairies are now being reclaimed by private capital at a very rapid rate in units of 5,000 and 10,000 acres and are offered for sale in tracts of 40 to 160 acres to those looking for new land. There are already nearly fifty of these reclamation projects under way, embracing something like 250,000 acres of land that is being made ready for settlement. 


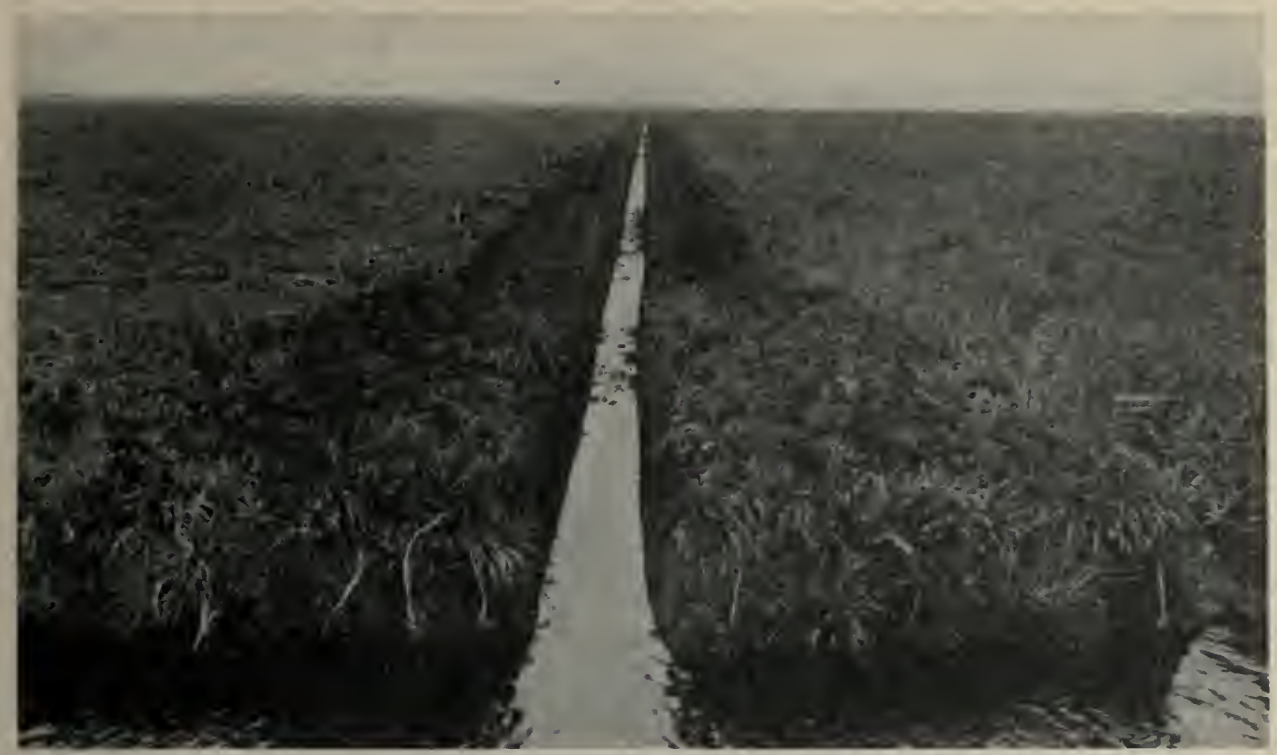

Drainage Canal Entering into Main Canal

\section{Reclaiming Marsh Prairies of the Delta}

The method of reclamation is simple, practical and of moderate cost, when compared with the cost of reclaiming, by irrigation, the arid lands either in Egypt or in the western part of the United States. The land is level and open, is covered with a luxuriant growth of marsh grass, and while appearing to be almost sea level, is in reality from three to five feet higher, but lacks sufficient fall to enable it to be drained by gravity.

In proceeding with its reclamation and preparation for cultivation, a tract of 5,000 or 10,000 acres of the marsh land is selected at random from a drainage unit. By means of a floating dredge, a canal is cut entirely encircling the tract, the excavated earth being thrown on the inside so as to form a surrounding embankment or levee some six or seven feet in height. The area thus enclosed is then supplied with a system of drainage canals cut every one-half mile apart, leading into a main outfall canal from which the water is removed by a pumping plant located at a point where this canal crosses the dam encircling the enclosed area. All the water is then removed from the enclosed tract, its level being reduced in the canals to five or six feet below the level of the water on the outside. As the soil is loamy in character, and as the top surface is almost pure decayed vegetation, the land dries out very rapidly, enabling the grass to be burned off and the land to be immediately plowed and prepared for cultivation.

The area thus reclaimed is then incorporated under the laws of Louisiana as a municipal district and drainage bonds are issued and sold to pay for the work of reclamation. The average cost of this is about \$35 per acre, distributed over a period of forty years. The bonds are a first lien on the land and draw five per cent interest, which together with the cost of maintenance and the sinking fund, is provided for by the levy of a special drainage tax amounting to about $\$ 2.50$ per acre per anmum.

Although the work of reclaiming this alluvial area lias been in progress but a few years, there are already quite a number of reclamation units in a highly flourishing and prosperous condition, with approximately 35,000 acres under cultivation, and as the lands become better known to prospective settlers throughout the corn belt states, there is a constantly increasing demand for them.

\section{Soil}

The soil forming this entire Alluvial Delta Area of 5,000,000 acres is pure Mississippi River silt. The top surface of the reclaimed marsh area, to a depth of two or three fect, consists of decayed vegetable matter, exceedingly rich in 
nitrogen, and beneath this are various types, designated by the United States Bureau of Soils as Sharkey clay, Galveston clay, Yazoo loam and Yazoo clay, all blending imperceptibly into one another. It is without doubt the very richest area of agricultural land on the American continent, and will produce in abundance every known crop grown in this latitude. As indicative of the fertility of the soil comprising this area, the following is quoted from the report of Professor Firman E. Bear, Ph. D., a member of the faculty of the College of Agriculture, Ohio State University, and Honorary Associate in Soil Fertility, who recently made an analysis of the soil:

"There is enough nitrogen present in the first eight inches of this reclaimed marsh land to supply nitrogen for 1,000 fifty-bushel crops of corn. I have never analyzed a soil with so high a percentage of nitrogen."

\section{Water}

While heretofore the native settlers throughout the Delta Area have depended upon rain water for drinking purposes, it has recently been ascertained that an abundance of excellent water can be obtained from artesian wells at a depth of from 200 to 300 feet. Wells have been struck on a number of the reclaimed tracts throughout the marsh area sufficient to demonstrate that a good supply- of water can be obtained on any farm for about $\$ 200$. However, there is such an abundance of rainfall so equally distributed throughout the year that an ordinary cypress tank of 2,000 gallon capacity will supply ample water for all domestic purposes.

\section{Crops}

For hundreds of years the staple crop grown on the higher portion capable of cultivation has been sugar-cane, so that this region has for many years been known as the "sugar bowl of the nation;" but the land is so rich and the climate so mild that almost any crop can be produced in abundance. Sugar-cane, corn, rice and vegetable truck are now the principal crops that are raised in the Alluvial Delta Region.

The reclaimed lands in the vicinity of New Orleans, because of their proximity to markets, are peculiarly adapted to the production of truck crops, such as onions, cucumbers, eggplant, cabbage, cauliflower, carrots, radishes, turnips, parsnips and lettuce for the Northern markets, yielding large returns to the grower.

The staple crops that are being depended upon, however, are sugar-cane and corn. The new virgin soil of the reclaimed area will produce large yields

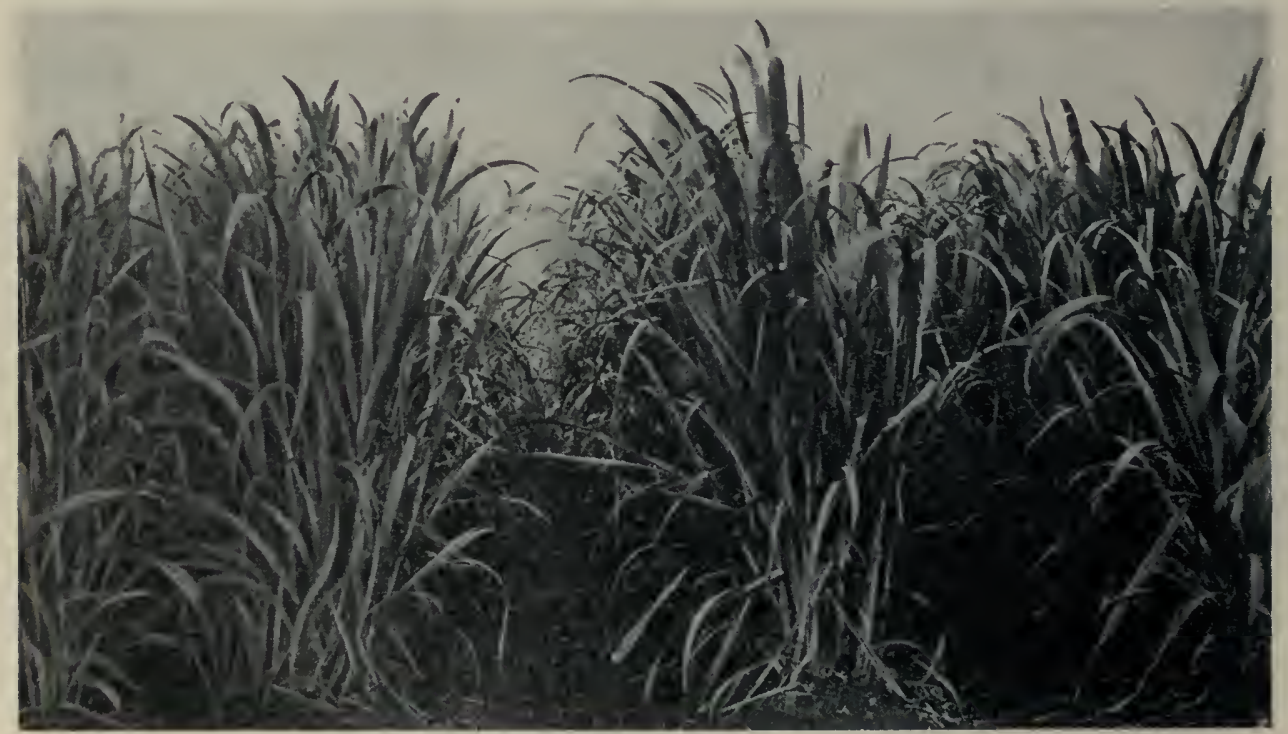

Louisiana's Cane Fieldsa are the Nation's Sugar Bowl 
of sugar-cane, marketable at the near-by sugar mills at profitable prices; while corn grown from selected seed will yicld on these new lands from fifty to one hundred bushels to the acre, depending on the individual care and cultivation. Compare these with the so-called corn-producing states and one can readily appreciate the value of this soil as corn land.

\section{ALLUVIAL BOTTOM LANDS}

The largest arca of the alluvial lands lies adjacent to the Mississippi River, and, although all of it was, in the early history of the State, subject to overflow, the whole region is now considered safe by the protection that levees of sufficient size and strength afford.

North of the mouth of the Red River there are about 3,000,000 acres of such land, fully 80 per cent of which is still undeveloped. South of the mouth of the Red River, on the west side of the Mississippi River, are those areas designated as the Atchafalaya Basin and the Lafourche Basin, while on the east side is the Pontchartrain Basin, the three areas aggregating about 6,500,000 acres. This includes the Alluvial Delta Region, already described separately in the preceding pages, as embracing about 5,000,000 acres, which leaves approximately $1,500,000$ acres in the upper part of the Atchafalaya Basin to be classed as alluvial bottoms and discussed under this heading. The remaining alluvial lands are to be found along the Red and Ouachita rivers, also protected by levees. These lands are nearly level, with a slight but sufficient slope towards the south and west to insure good drainage by gravity when proper ditches and canals have becn cut, and although most of the area is now covered with bottom land timber, this is being rapidly removed by the numerous hardwood lumber companies and the lands are being made available for cultivation.

These are some of the richest and most valuable lands in the State and consist largely of those types of soil known as Yazoo loam and Yazoo clay, which is found in one unbroken area south and southeast of Baton Rouge. The Yazoo clay is the soil type of greatest extent, and by far the most important agriculturally, in the Mississippi bottoms.

Sugar-cane is the principal crop of the alluvial bottom lands below Red River, while cotton and corn are the chief crops in the portion above Red River. Alfalfa is also grown extensively in these upper alluvial bottoms along the Mississippi, as well as in those lands bordering Red River. The major portion of the alluvial lands south of Red River are devoted to cane culture, with corn as a rotation crop.

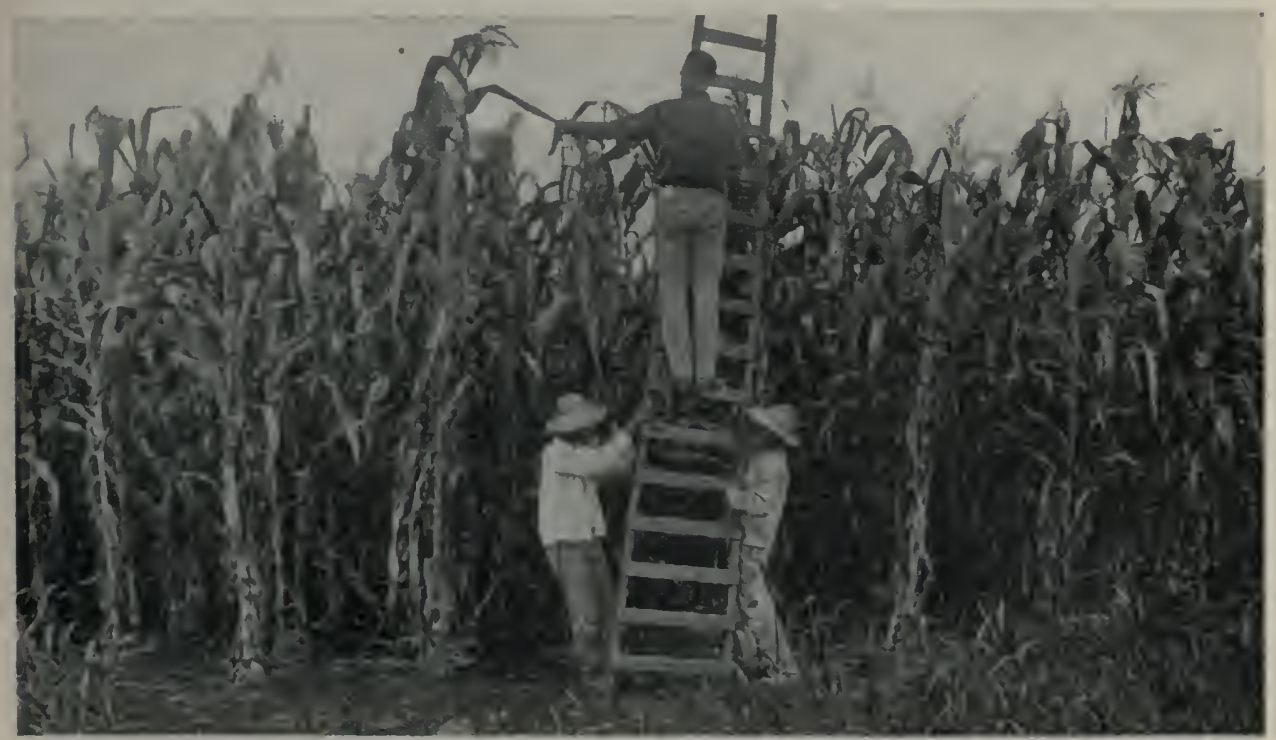

Corn Thrives on Alluvial Lands- 50 to 100 Bushels per Acre 
Cotton, corn and alfalfa are the chief crops produced on the alluvial bottom lands above the sugar-cane regions. Those in the Tensas, Macon and Boeuf basins above Red River contain some of the finest producing lands, and with proper care and cultivation and adequate drainage, will yield from one to one and a half bales of long staple cotton to the acre.

Corn is by far the most profitable crop that can be raised by the average farmer on the alluvial bottom lands of Louisiana since the introduction of better methods of cultivation.

Not only are the alluvial bottom lands of the State the best that can be had for growing of such staple crops as sugar-cane, cotton and corn, but they are also ideally situated for live-stock raising and the production of meat. There are thousands of acres of rich alluvial bottom lands awaiting the settler, that can be had at very low prices.

\section{BLUFF LANDS}

The Bluff Land Section embraces an area of about 2,000,000 acres. These lands are from 80 to 200 feet above sea level and have not been in any way affected by the Mississippi River floods. The land is quite fertile and preferred by some to the alluvial bottom lands.

There is an abundance of good water from springs, streams and wells. The land is somewhat hilly and is well adapted to dairying, live-stock grazing, truck raising and generally diversified farming, including the following crops: Cotton, corn, sugar-cane, oats, hay, sweet potatoes, Irish potatoes and peanuts.

Cotton is by far the most important crop, yielding in good seasons about three-fourths bale per acre. Corn returns from fifteen to twenty-five bushels. Lespedeza is highly prized for pasturage or hay. It yields about one ton per acre, and in addition is a valuable fertilizer. Cowpeas are occasionally sown in the corn for forage and this practice is to be commended. Crab grass grows spontaneously and makes a good hay, yielding from one to two tons per acre. Oats do well in this, as well as all other sections of Louisisana. Seed may be sown from early October to the middle of December and the crop harvested the following May. An average yield for what would be classed as a good crop is around forty bushels per acre, and sixty bushels may be obtained in exceptionally favorable conditions.

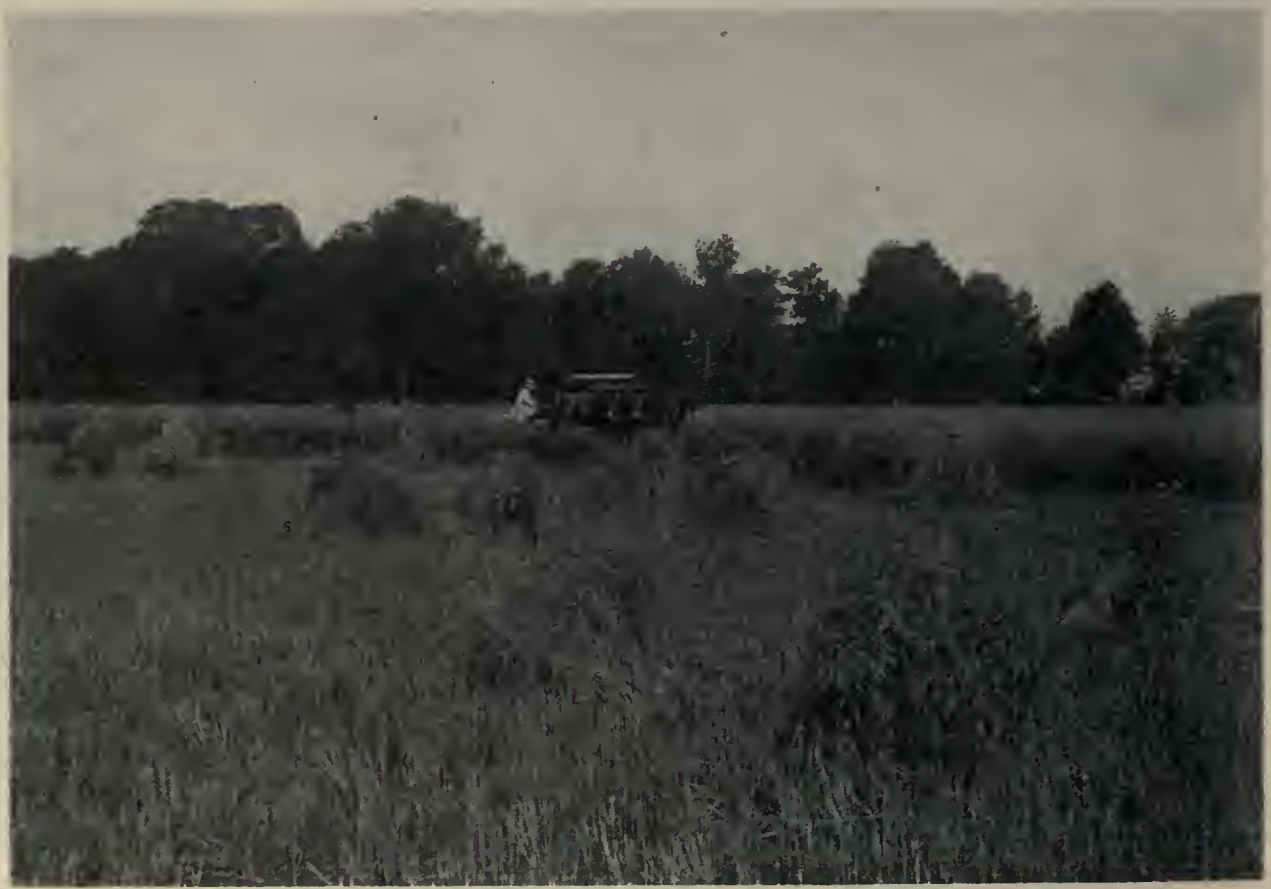

Harvesting Oats in May. Average Yield 50 Bushels per Acre 


\section{PINE HILL LANDS}

The Pine Hill Lands embrace an area of about 4,900,000 acres, located about the central part of the State on both sides of Red River, with a small portion lying east of the Mississippi River north of New Orleans. These lands are commonly known as the cut-over pine lands, which can be bought on very reasonable terms, and which are excellent for diversified crops.

The following is an extract from a survey made from this portion of the State:

"It is only within the last few years, since the timber has been so largely removed and the agricultural population of the region has increased, that any considerable areas of this soil have been under cultivation. Its location is excellent, thus insuring good drainage; it responds readily to fertilization and holds moisture well during the summer, while its fine sand content makes it an easy soil to work. With these advantages it is well adapted either to truck growing or to general farming. At the present time it is used for all of the general crops of the region, besicles such special crops as strawberries, cabbage, radishes, lettuce, tomatoes, and other trucking crops. With ordinary care and attention cotton will average one-half bale per acre. Corn will average about twenty bushels per acre, although as much as fifty bushels per acre is sometimes grown after some highly fertilized crop. There is a moderate acreage in oats and satisfactory yields are secured. Trucking is becoming a very profitable industry, and the profits from a single acre are sometimes $\$ 200$ to $\$ 300$ or more, depending upon the season, the market and the care and attention given to the crops."

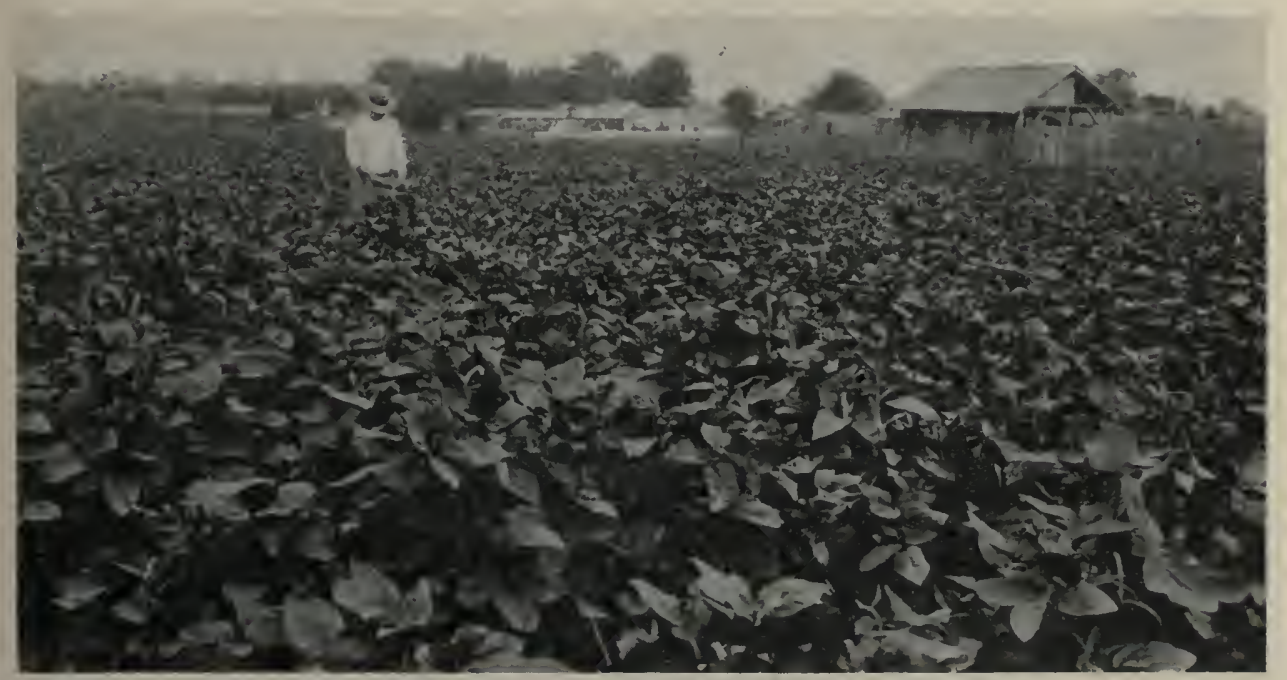

Soy Beans a Good Hay and Silage Crop for Louisiana

The crops most usually planted in the Pine Hill Lands are cotton, corn, sorghum, oats, peanuts, sweet potatoes, velvet beans and soy beans. Cotton is the staple crop, but it is giving way rapidly to diversified farming, more attention being now paid to the raising of oats, hay, clover and velvet beans, and the production of cattle and hogs.

\section{PINE FLATS \\ (Cut-Over Pine Lands)}

The Cut-Over Pine Lands of Louisiana occupy an area of about $1,300,000$ acres located in the southwestern portion of the State and east of the Mississippi and north of Lake Pontchartrain. Because of their advantageous location to markets and the low price at which the land can be bought, the truck grower, the farmer, the dairyman, the sheep grower and the cattleman are rapidly investing their money in these lands. 


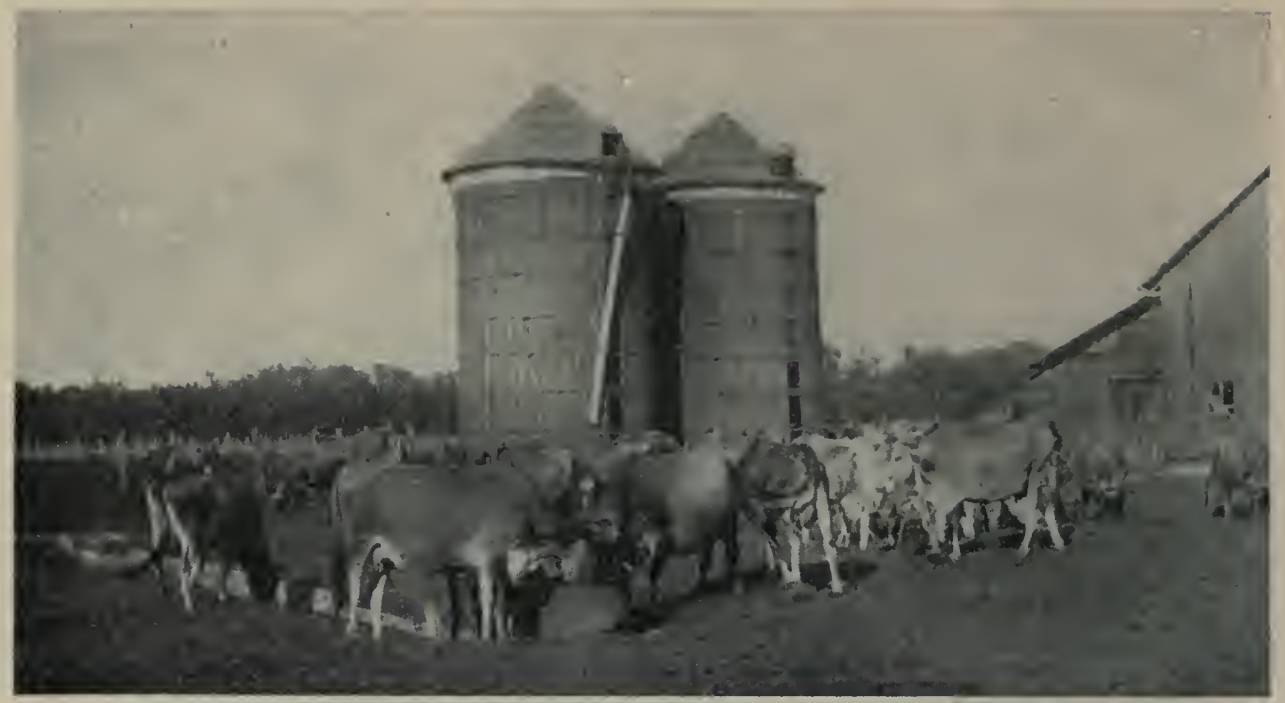

75 Per Cent of the Milk Shipped to New Orleans Is from the Cut-Over Pine Lands

It would be next to impossible to do any one section, or division, of this great State justice, even though the entire booklet were devoted to it. This is especially true of the Cut-Over Pine Lands, and we will, therefore, call the attention of the homeseeker to a few of the outstanding facts concerning the above territory.

(1) Ninety per cent of all the sheep in Louisiana are on cut-over land.

(2) Eighty per cent of the sweet-potatoes that are shipped from the State are from the cut-over land section.

(3) All the strawberries are from the cut-over section.

(4) Seventy-five per cent of the milk shipped to New Orleans is from the cut-over lands.

(5) The cut-over section leads in the production of velvet beans, soy beans, and is best adapted for peanuts.

(6) The very best cabbage, cauliflower, beets, snap beans, and in fact all kinds of vegetables, are grown and shipped from the cut-over lands.

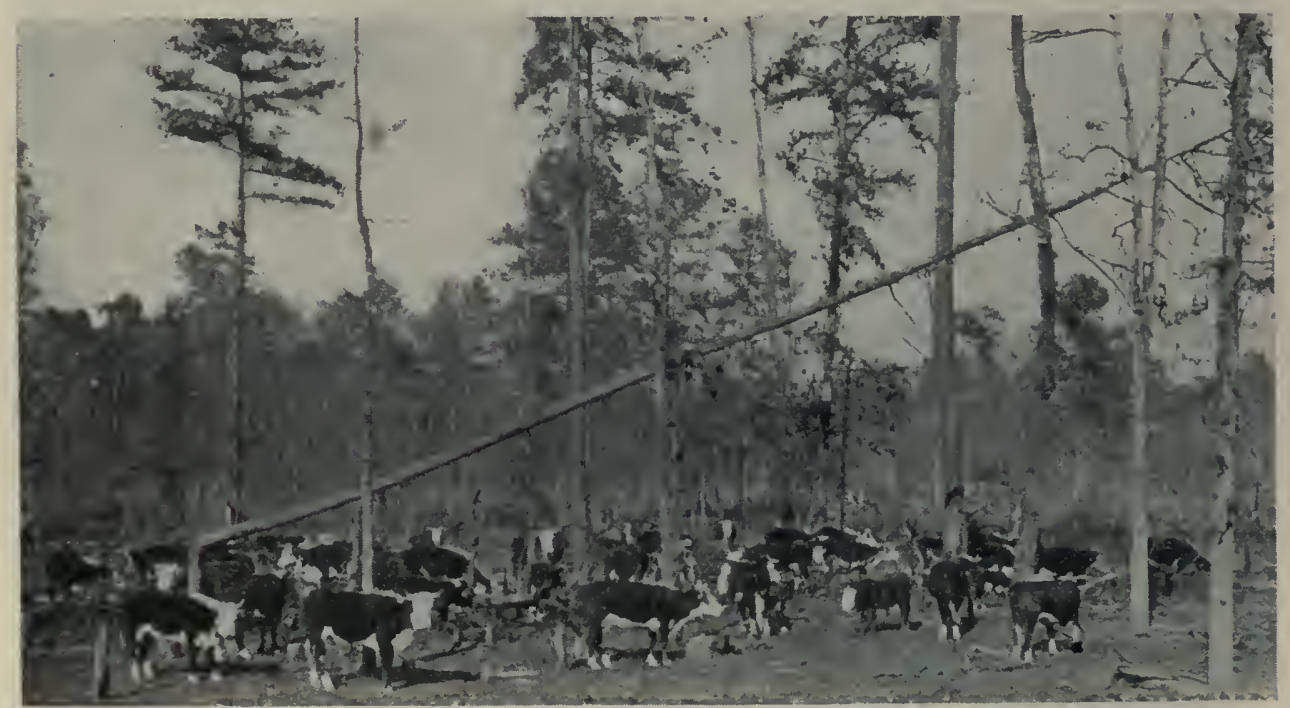

Cut-Over Pine Lands - an Attractive Field for the Ranchman 
In addition to the above, very fine crops of corn, oats, Irish potatoes and cotton are grown.

This territory has been termed "The Ozone Belt" of the State and every winter thousands of people from the Northern States flock to this section to bask in its sunshine, to inhale the fragrance and enjoy the beauty of its flowers, and to quaff of the water of eternal youth flowing from artesian wells at a depth of over 2,000 feet.

\section{UPLAND SECTION}

The Uplands of Lousiana occupy an area of about 5,500,000 acres, lying in the northern and northwestern portion of the State. The land is hilly and rolling, usually covered with hardwood and pine. The soil is not rich, but by growing legumes and rotation of crops can be made very productive and can be bought at prices exceedingly attractive.

As in nearly all of the other sections of the State, except the Prairic Section and the Alluvial Delta Section, cotton and corn are the leading staple crops in the Upland Section. Other crops, such as oats, clover, hay, sorghum, peanuts and sweet potatoes are grown with good success, however, as the land is enriched by cultivation of cowpeas, velvet beans and soy beans. Lespedeza clover is now receiving considerable attention in Louisiana as a hay crop and is being grown with great success, not only in the Bluff Land, but also throughout the northern parishes constituting the Upland Section.

Sweet potatoes are grown in all parts of the State, but especially throughout the Pine Hill Lands and the Uplands. The crop is a valuable one to the State and in 1918 amounted to $\$ 6,240,000$, ranking sixth in the value of crops. The sweet potato is becoming better known and appreciated throughout the North and the more thickly populated sections of the United States and as a result, there is constantly increasing demand, so that in time it, too, will become quite a profitable crop. Of recent years canning factories have been established and a larger portion of the crop is now put up and marketed in this manner.

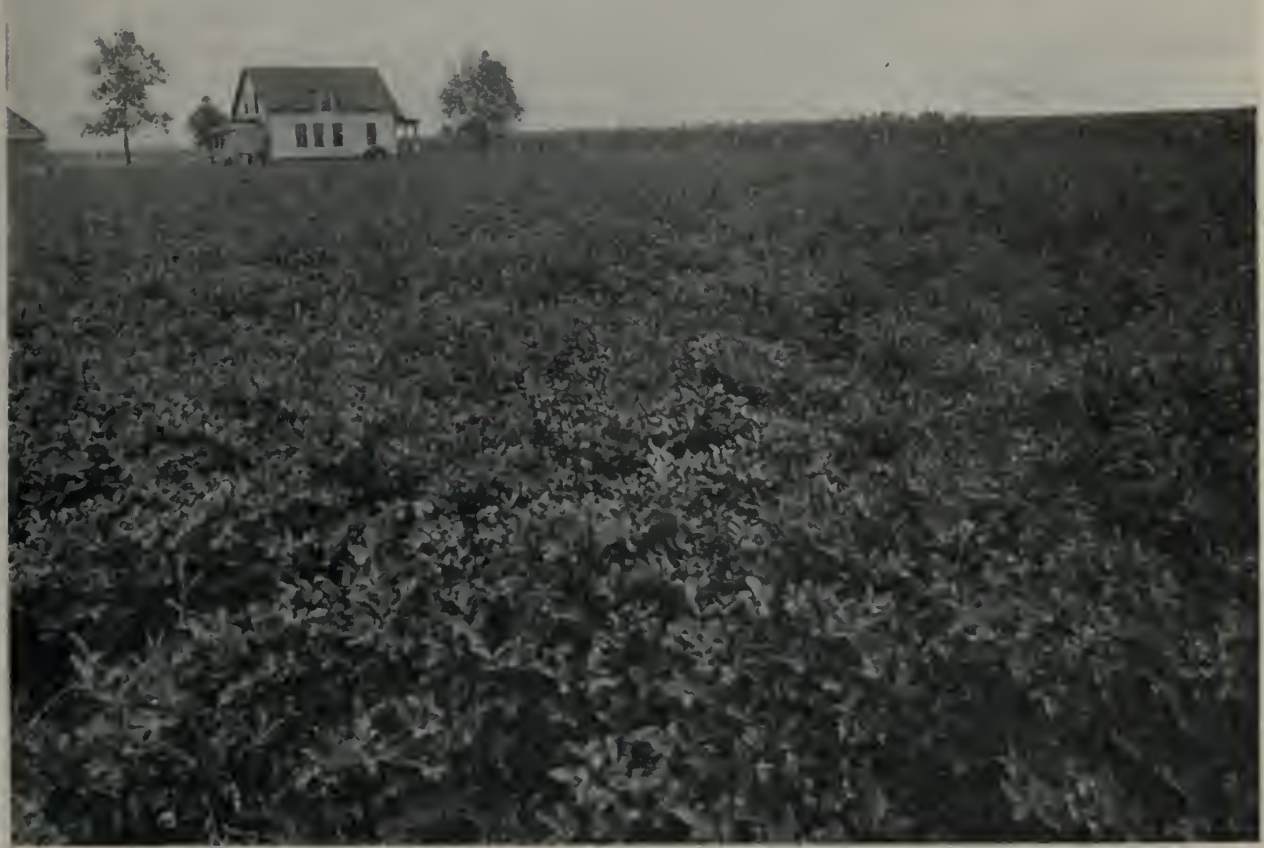

Peanuts - a Profitab!e Crop for Live Stock 


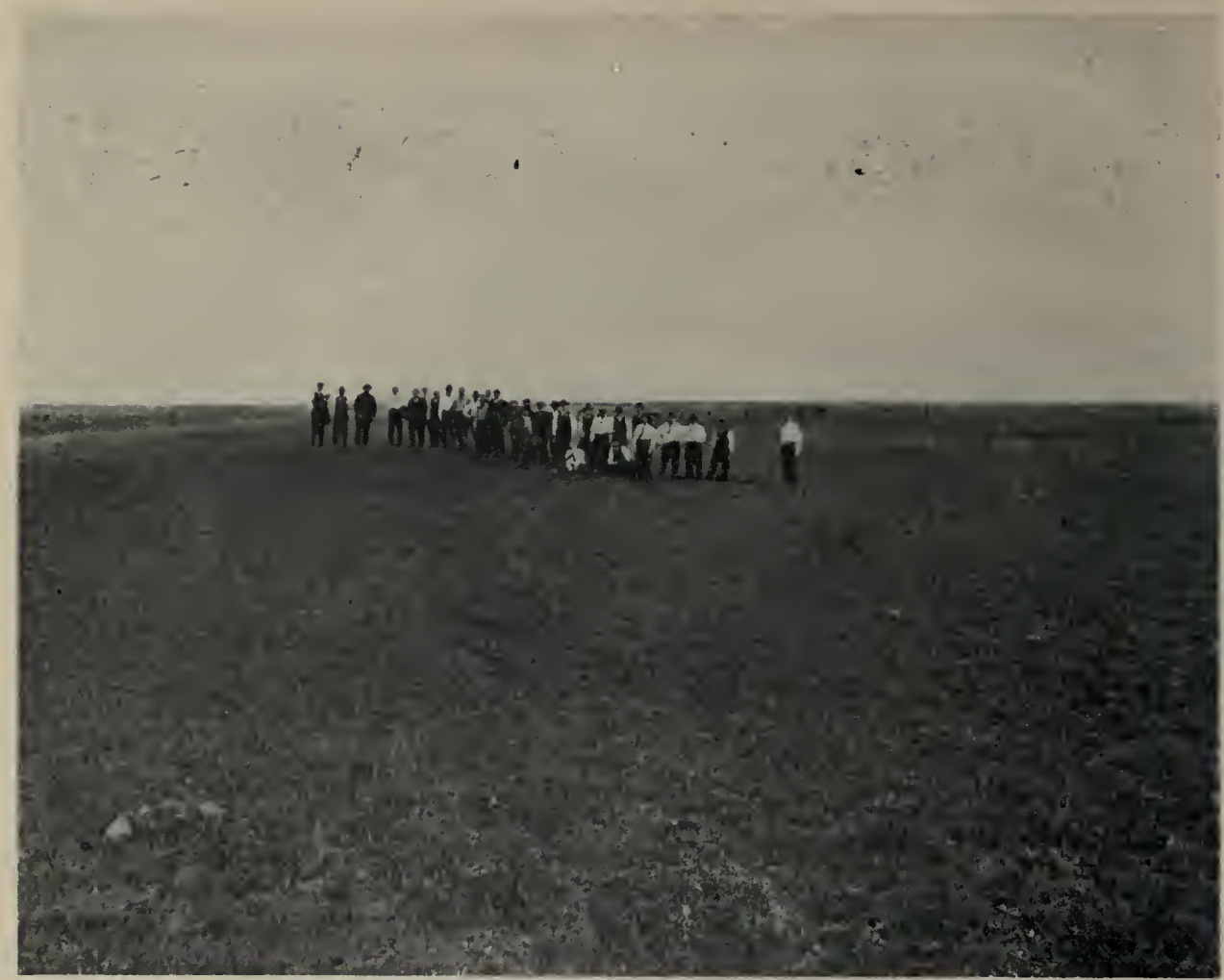

Party of Homeseekers in the "Prairie Countrv." 40,000 Acres Settled by Northern Farmers in Sixteen Months

\section{ATAKAPAS PRAIRIE SECTION}

- The Prairie Lands situated in the southwestern part of the State and embracing an area of about 2,500,000 acres, are located in the Parishes of Calcasieu, Davis, Vermillion, Lafayette, Acadia, St. Landry, Evangeline, Allen and Iberia. The soil is composed of broken down bluffs and the land is open, generally rolling, and gradually slopes towards the sea.

One may obtain quite an accurate idea of the Prairie Lands from the following authentic report taken from the soil survey of that parish by the United States Government made in 1903:

"The soil types of the prairie region as a whole may be fairly judged by a description of the soil in Acadia Parish located about the center of this area. The United States Soil Survey of this parish shows seven distinct types: Crowley silt loam, Acadia silt loam, Landry silt loam, Lake Charles fine sandy loam, Swamp and Galveston clay. The Crowley silt loam is the typical rice land of southwestern Louisiana. By structure, topography, texture and productiveness it is peculiarly adapted to the growing of rice on a large scale and at a minimum expense. The soil ranges in depth from ten to twenty-five inches, but the usual average depth is about sixteen inches. It is a brown, ash gray loam, composed of fine sand and silt, with a sufficient proportion of clay to give it a loamy cohesiveness and to render it impervious to such a degree that pools of water collecting on the surface usually remain until evaporated.

"The healthfulness of this section has been thoroughly established. Although a large number of the immigrants to the rice belt have come from northern latitudes, thay have had no difficulty in becoming accustomed to the climate. The standing water on the rice fields has not been observed to have any detrimental effect upon the health of the community." 


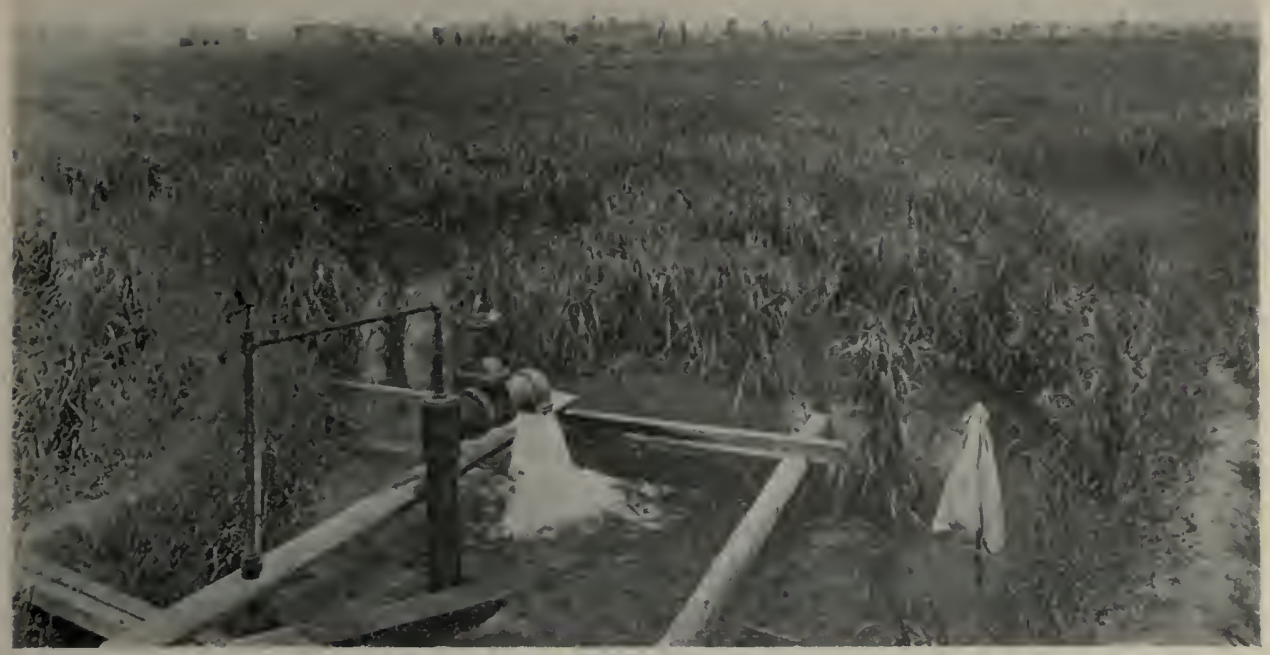

Irrigating Rice

\section{Crops}

Prior to 1884 most of this area, like the prairie lands of Texas, was given over to cattle grazing, although a small portion of it was devoted to the cultivation of cotton and corn in scattered locations. About that year, it was ascertained these lands could be artificially irrigated and made available for the growing of rice, the cultivation of which has spread rapidly throughout the entire Prairie Land Region and is the largest area of land in the United States devoted to raising of rice.

The staple crops of cotton, corn, sugar-cane, sweet potatoes and all varieties of garden truck, together with every variety of grass and clover do exceptionally well and are grown in all parts of the Prairie Land Section.

This is in reality Acadia - the part of Louisiana made famous by Longfellow's "Evangeline" and is one of the most interesting and attractive sections in the South. Nearly all of the native inhabitants are the descendants of those FrenchCanadians, who, driven out of Nova Scotia by the English, came to Louisiana and settled in this delightful country, "Where the grass grows more in a single night than in a whole Canadian summer."

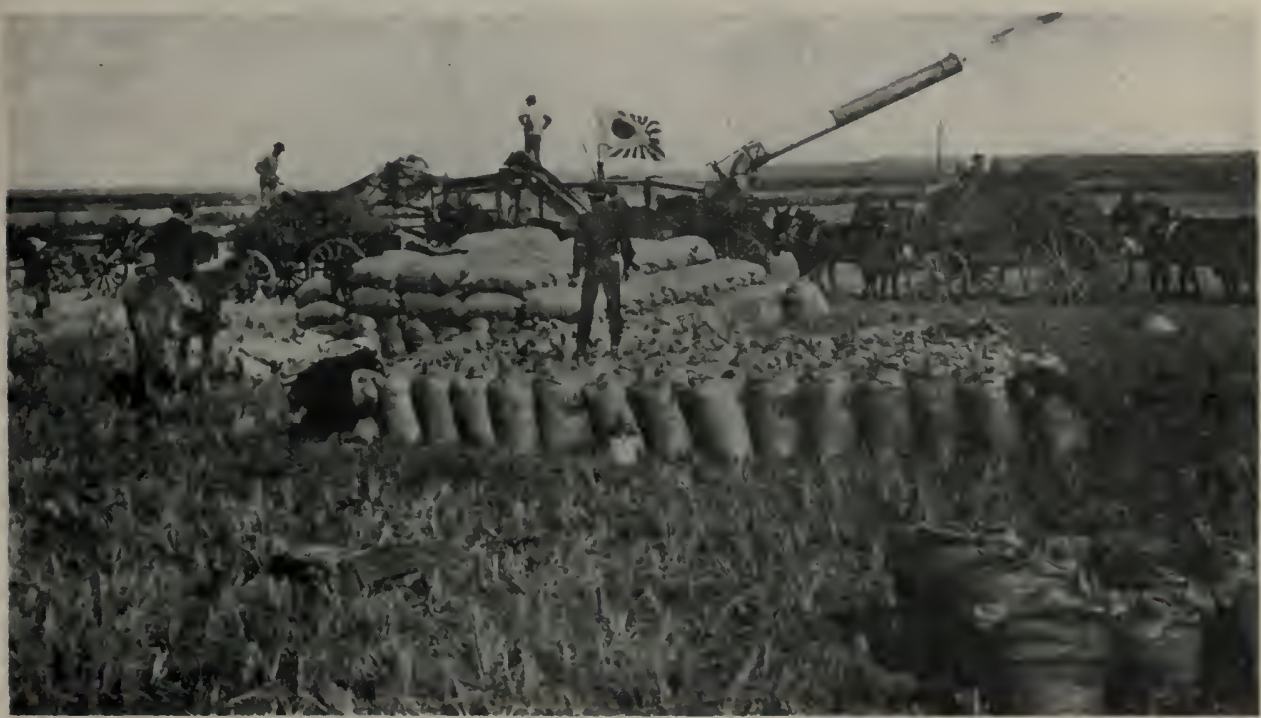

Threshing_Rice 


\section{SEA COAST MARSH LANDS}

The Sea Coast Marsh Section as distinguished from the Alluvial Marsh Section east of the Atchafalaya River, embraces an area of about 200,000 acres lying just south of the prairie lands adjacent to the Gulf in the parishes of Cameron and Vermillion. These marsh lands are for the most part flat, undrained areas very slightly above sea level, whose top soil consists of washings from the prairie lands above, mixed with decayed vegetable matter, entirely different in character from the Yazoo loam, Yazoo clay and Sharkey clay, formed by deposits from the waters of the Atchafalaya and Mississippi rivers.

The land is susceptible to reclamation by the same methods that are now being pursued in the Delta Marsh Section and will undoubtedly prove very valuable when thus reclaimed. There is a considerable area of this section that is capable of drainage by gravity and this scattered acreage is now available for settlement, and is proving to be very desirable land. As may be supposed the climate in this section is very mild in winter and the summer temperatures never run high, because of the proximity to the Gulf.

Rice and sugar-cane are the staple crops there now, but the fertility of the soil and extremely mild winter climate make it an ideal region for the growing of citrus fruit.

Reclamation of these lands has already begun and quite a large area is now being developed by Northern capital in the vicinity of White Lake in Vermillion Parish. If these areas are properly leveed and drained and if the drainage districts formed under the direction and guidance of the State Board of Engineers are equipped with adequate pumping plants, there is no reason why thousands of acres of very desirable rich land cannot be made available for settlement at an early date, but, as in the reclaimed Delta Marsh Land Section, great care should be exercised by the newcomer to see that the land he is purchasing is located in a district that is properly organized and adequately equipped for complete and thorough reclamation. Lands thus reclaimed will produce abundant crops of corn, sugar-cane, onions and Irish potatoes, besides affording every opportunity for raising cattle and hogs at a lower cost than they can be raised anywhere else in the country.

Sea-island cotton is being grown in parts of this region near the Gulf as an experiment and as all of the elements essential to the successful growing of this variety of cotton are to be found here, it is not unlikely that when reclaimed, the Sea Coast Marsh Lands of Louisiana will become one of the most productive sources of this grade of long-staple cotton in America.

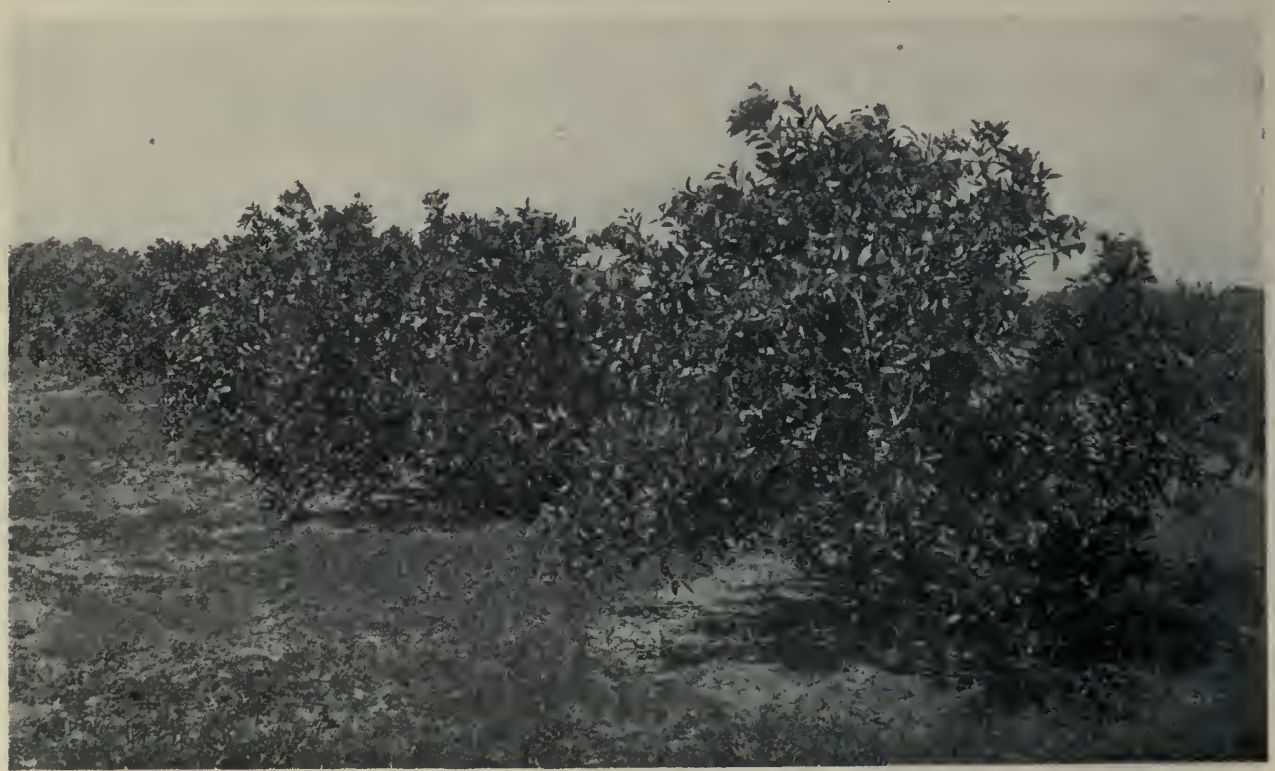

Sea Coast Marsh Lands Ideal for Citrus Fruits 


\section{LIVE STOCK}

One of Louisiana's greatest needs is more and better live stock, through which to market her native feeding materials and others which may be inexpensively raised, and help increase and maintain the fertility of her lands, which previously had been more or less depleted through a prevailing system of single cropping.

Up to the present Louisana has not even approached the point of maximum production, either in food crops or in the number or quality of her live stock, to be able to successfully compete in the metropolitan markets with the more advanced sections of the country. But with her possibilities for greatly increased feed production of almost every variety and with a vastly increased number of animals, especially of the meat producing kinds, it is only a question of time when she will be able to take her place among the most advanced.

That Louisiana is a live-stock State is proven by .the fact that she already has within her borders representatives of all the modern, improved kinds of farm animals and a great majority of the different breeds, especially in cattle (both beef and dairy) and in hogs; and is in a fair way to become a sheep section, more particularly in the cut-over pine regions.

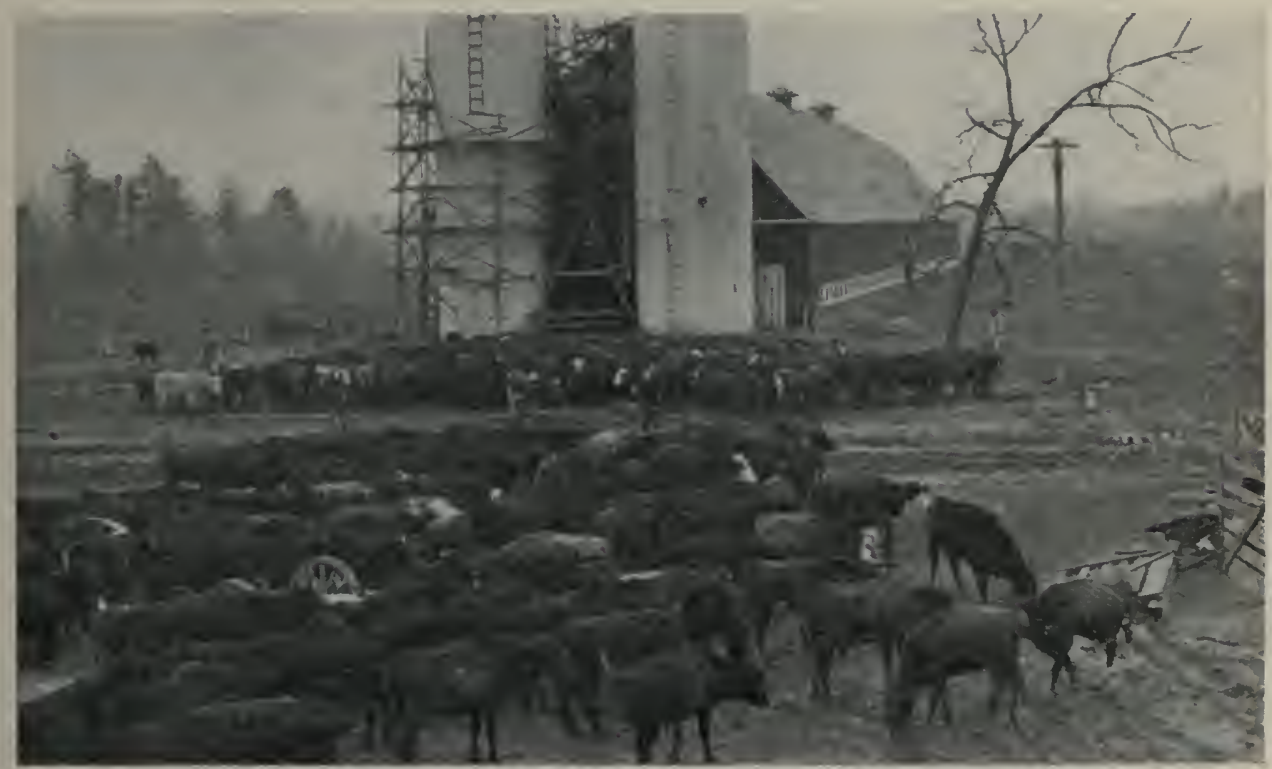

No Section of the Country Can Produce Cattle More Cheaply than Louisiana

\section{Cattle}

The chief obstacle to the successful raising of cattle hitherto has been the presence of the common cattle tick-the carrier of the germ of Texas or Tick Fever-which not only caused the deaths of a considerable percentage of imported animals for breeding purposes, and placed a severe check on the development and production of native stock, but practically closed the Northern markets to her cattle. This state of affairs, however, is virtually a thing of the past, and by the close of 1919 the entire State will be practically tick-free. This means free access to all markets; the elimination of the danger to imported, susceptible cattle; greater development of both beef and dairy stock, and the placing of the State, with her cattle interests, on a par with those that have never suffered from this particular incubus.

The breeds of beef cattle at present represented in the State are the Shorthorn, Polled Durham, Hereford, Aberdeen Angus, with a few Brahmans in some sections. Of the smaller breeds there are the Devon and Red Poll.

Of the dairy breeds there are the Jersey, Guernsey and Holstein mainly. The dairy industry is being developed to quite a large extent in sections easily accessible to the larger cities and towns and convenient to lines of transportation. 


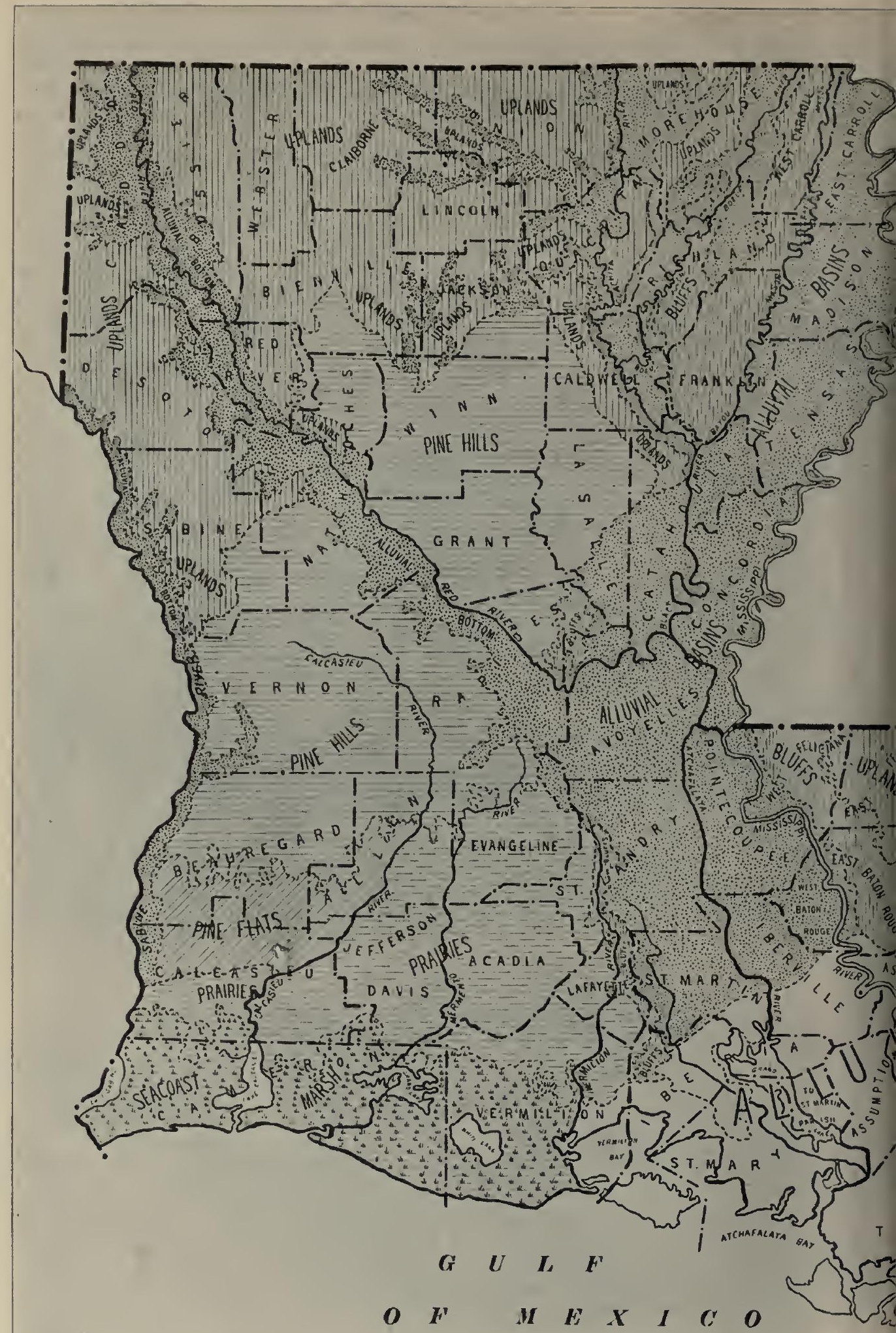




\section{LOUISIANA}

"I doubt very much if there is another State in the Union where one can as easily grow an abundant supply of those things that make good home living on a small area and leave the major portion of the land and the energy of the farmer to the production of money crops."

-W.R. DODSON

Dean of the Louisiana College of Agriculture and Direclor of the Slate Experiment Slation.

\section{(An Acroslic)}

Leads the world in the production of salt and sulphur.

On her farms is produced $95 \%$ of the sugar cane.

Under her lands are vast fields of oil and gas.

In manufactures she stands second in the South and sixth in the Nation.

Save one, she produces more lumber than any other State.

Inside her borders is the greatest mileage of navigable waterways.

Alluvial land - the largest area of any State.

New Orleans is the second largest port on the Atlantic.

Agriculture is the principal industry of her people. 


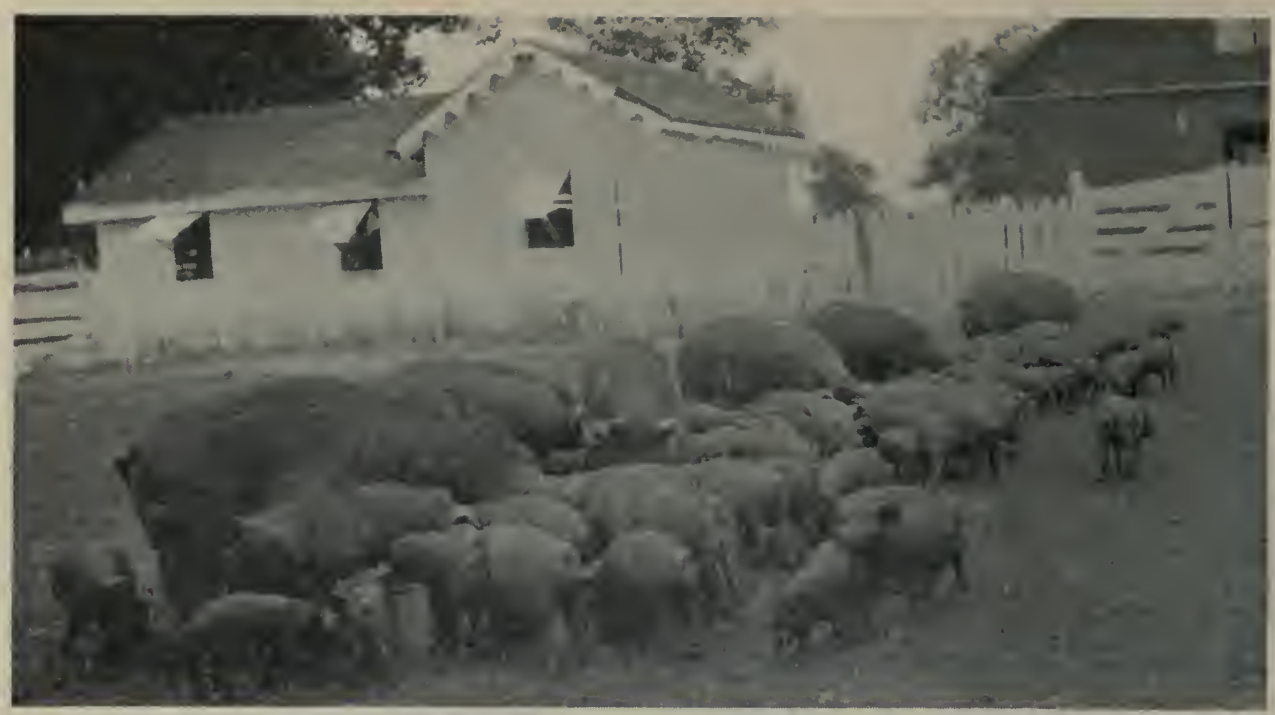

Hogs the Most Profitable of All Live Stock

\section{Hogs}

Hog raising is more generally practiced throughout the State, perhaps, than any other branch of the live-stock industry and, on the whole, is very successful and profitable, with a superior class of animals being the rule rather than the exception. One of the greatest stimuli to this branch of the industry has been the Boys' Pig Clubs fostered and encouraged by the co-operative action of the Federal Government, the Extension Service of the Louisiana State University and local interests. All varieties of crops suitable for hog feeding can be raised both of a succulent and concentrated character, at a minimum cost, when intelligently handled.

We believe we are correct in the statement that more money changes hands in the State every year as the result of hog production than from any other branch of the live-stock industry. It may be stated here that while hogs are subject to their diseases, like other animals, Louisiana has its Live-Stock Sanitary Board, or "Health of Animals Department," whose chief efforts are to try to prevent, control and eradicate diseases of a contagious nature, including cholera, and has a plant of its own for the production of serum, which hog owners may obtain at a minimum cost.

Of the different breeds of hogs in the State may be mentioned the Duroc Jersey, Berkshire, Poland China, Hampshire and a few Tamworths and Essex. There are also some Yorkshire and other varieties of the white-skinned breeds. If one should be guided by numbers the Duroc would seem to be the more generally popular breed.

\section{Sheep}

Sheep raising in Louisiana may be said to be in its infancy, although the conditions are favorable and the possibilties great, which are gradually coming to be realized. But in the aggregate the State possesses quite a large number of sheep on the different piny woods ranges, which up to the present have been of a somewhat inferior quality and kept mainly for their annual wool-clip, which costs the owners but little to produce. Of later years, however, a considerable number of pure-bred rams have been imported for grading purposes with resultant improvement generally, in both mutton and wool kinds. Still there is great room for improvement and with the possibilities for success in this important branch of husbandry in the hands of men thoroughly familiar with it, there is no question that it could be made most profitable, especially in mutton production primarily, either as a farm or as a range proposition.

A good many of the Down or mutton breeds are represented, such as the Shropshire, Hampshire, Southdown, some Horned Dorsets and Merinos, chiefly the Rambouillet. 


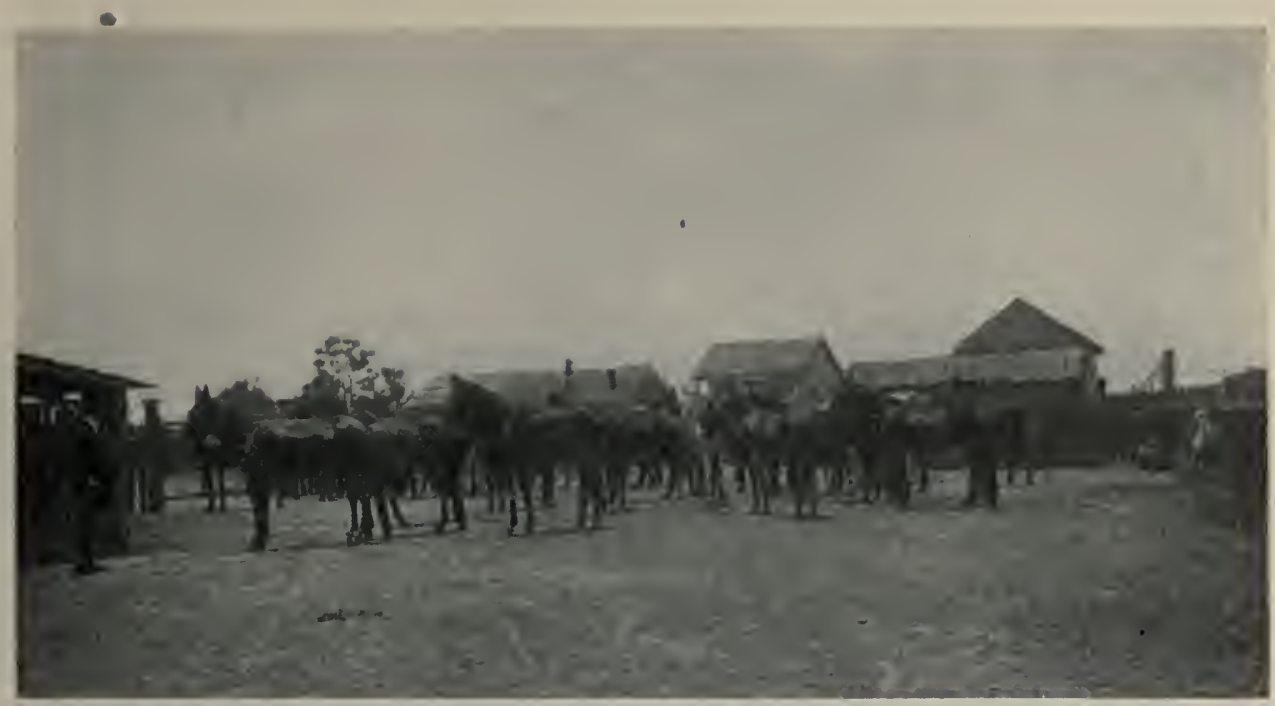

As Good as Grown in Missouri

\section{Horses and Mules}

Horses and mules are raised in Louisiana that are as sound and good as those in any other section. The large draft breeds of horses have not as yet gained much of a foothold on account of the mule having been, and still being, the principal draft animal and seems better suited under present conditions. Many farmers, however, are gradually adopting horses of the heavier breeds, which seem to be giving satisfactory results, especially in the hands of the more intelligent class of men. Of the breeds of horses of lighter weight, there are to be found the Oldenburg Coach, French Coach, English Hackney, "Kentucky" Saddle Horse and the Standard Bred, which latter is rather extensively raised for light harness purposes. With the proper foundation stock, as fine mules may be raised in Louisiana as anywhere, and up to any desired size.

\section{Significant Facts}

Live stock as a whole enjoys excellent health in the State and is as free from diseases as in any other parts of the country, though outbreaks of anthrax occasionally occur in some sections, but this may be controlled by intelligent preventive and other sanitary measures.

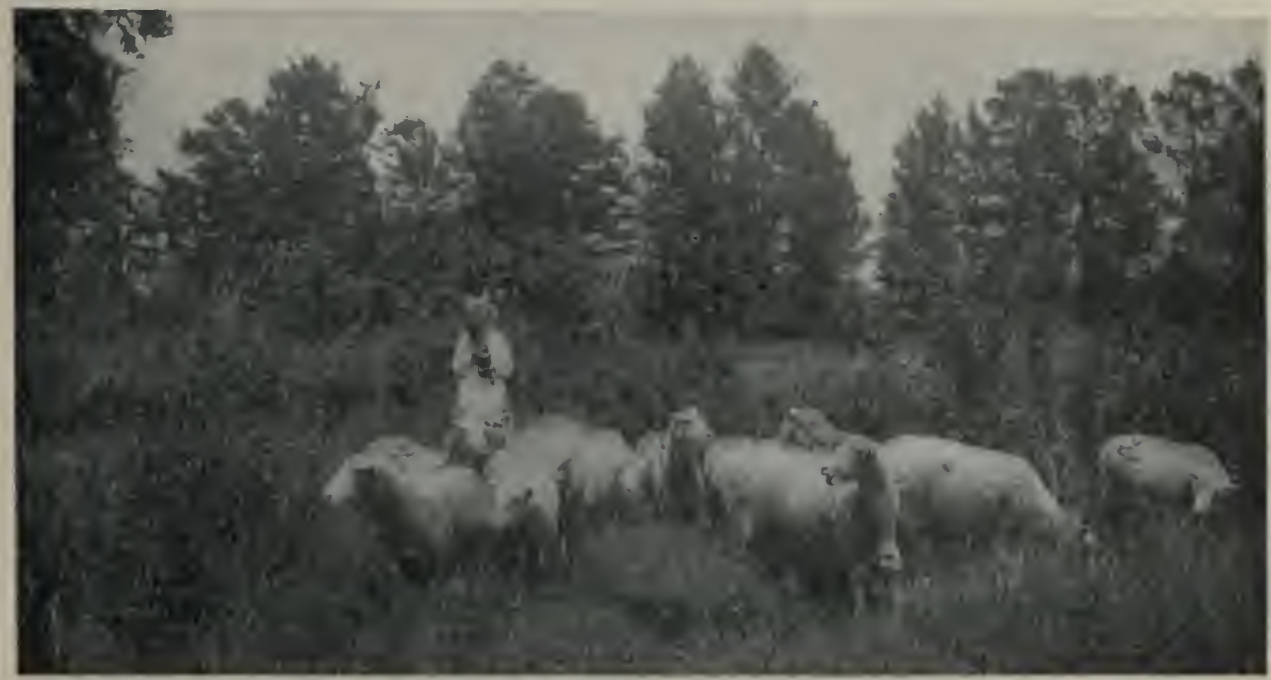

Conditions Favorable for Sheep Raising 
There is, or can be, an abundance of feedstuffs grown to meet the requirements of any and all varieties; and the State is exceptionally favored with an abundance of pure wholesome water from rivers, bayous, springs, artesian wells, etc., which is a most valuable and indispensable item in connection with stock raising of any kind. It may be further stated, as showing the interest in the live-stock industry already existing in the State, that almost every branch has its live-stock organization or association to foster and encourage its particular interests. Of these may be mentioned the Louisiana Dairymen's Association, the Louisiana Jersey Breeders' Association, the Louisiana Swine Breeders' Association, etc., whose memberships are composed of some of the leading men of the State.

There is no question as to Louisiana's possibilities as a live-stock State. She has everything needed to make her such, except that she needs more good farmers, or stockmen, who are thoroughly familiar with the more intelligent and practical side of the live-stock business to help her realize to the full extent the possibilities she possesses in abundance, and which are simply awaiting greater development.

\section{DAIRYING}

Dairying is diversified farming in the truest sense of the word. It is the gateway to prosperity. It is farming on a cash basis. It is intensified farming. It is profitable farming. And the State of Louisiana offers splendid opportunities for profitable dairy farming. The development of this industry on an extensive scale awaits the influx of people who understand the handling of stock and the production and proper handling of dairy products.

The advantages of this phase of farming in Louisiana are especially attractive because of the long pasturage season, the plentiful supply of rich feedstuffs and the nearness to large markets like New Orleans, Baton Rouge, Alexandria and Shreveport, where there is at all times a ready market for dairy products, the supply not equaling the demand. As a rule the price paid for milk, butter and cream is the same as paid in the dairy states of the North.

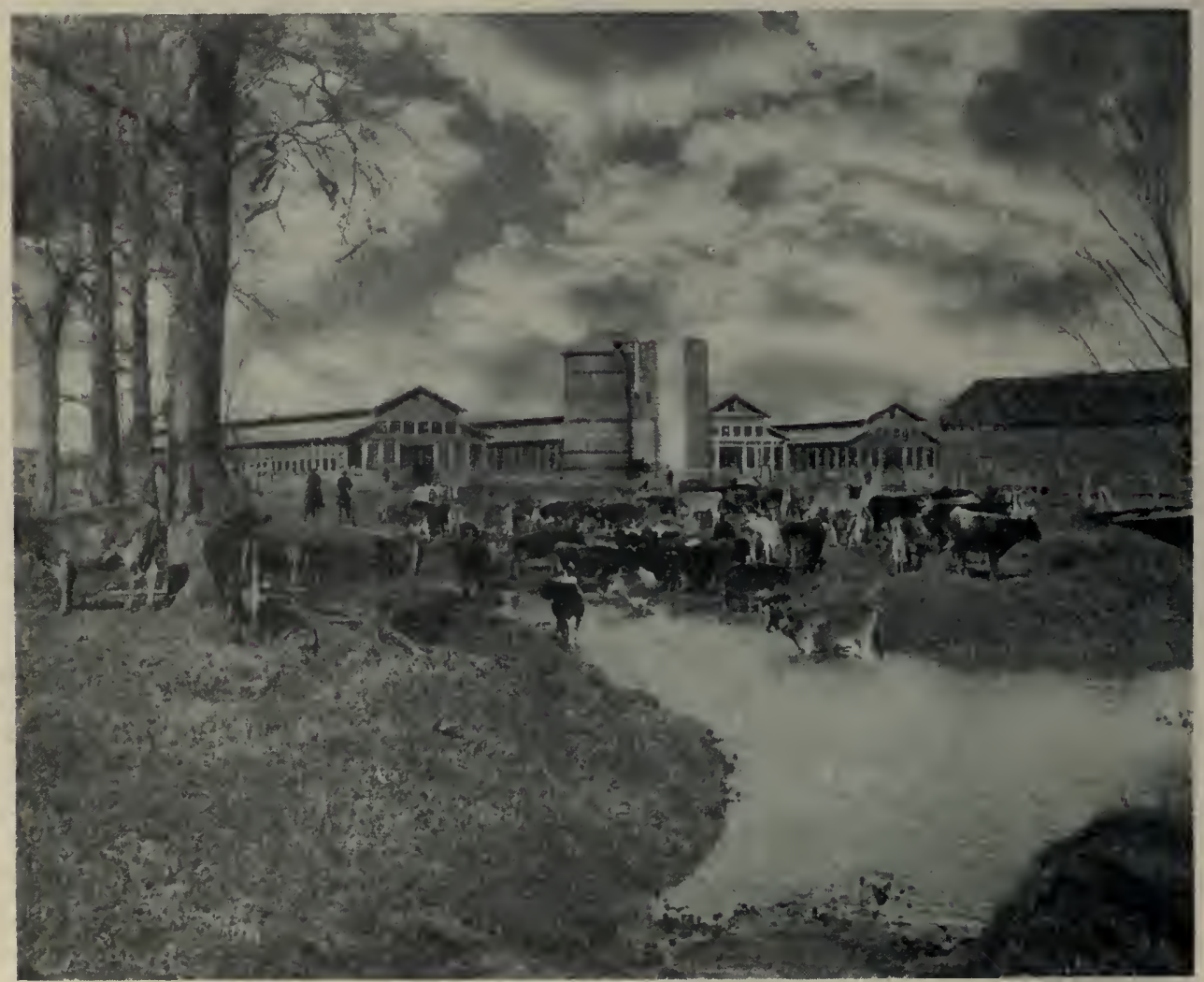

Dairying Is the Gateway to Prosperity 


\section{CROPS}

The principal crops of Louisiana are cotton, sugar-cane, corn, rice, sweet potatoes, hay crops, truck crops, velvet beans, soy beans, oats, peanuts, tobacco and citrus fruits.

The Commissioner of Agriculture and Immigration for the State of Louisiana furnishes the following estimate of crop values for the year 1918:

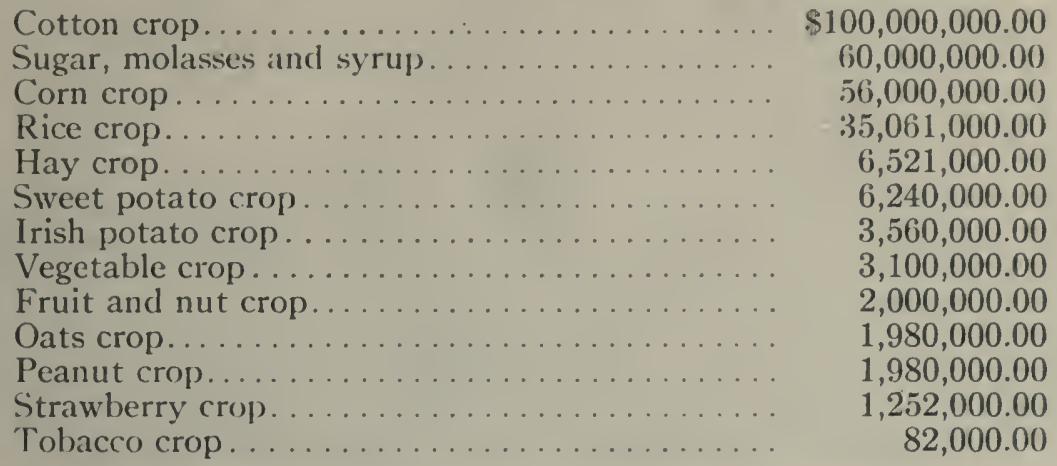

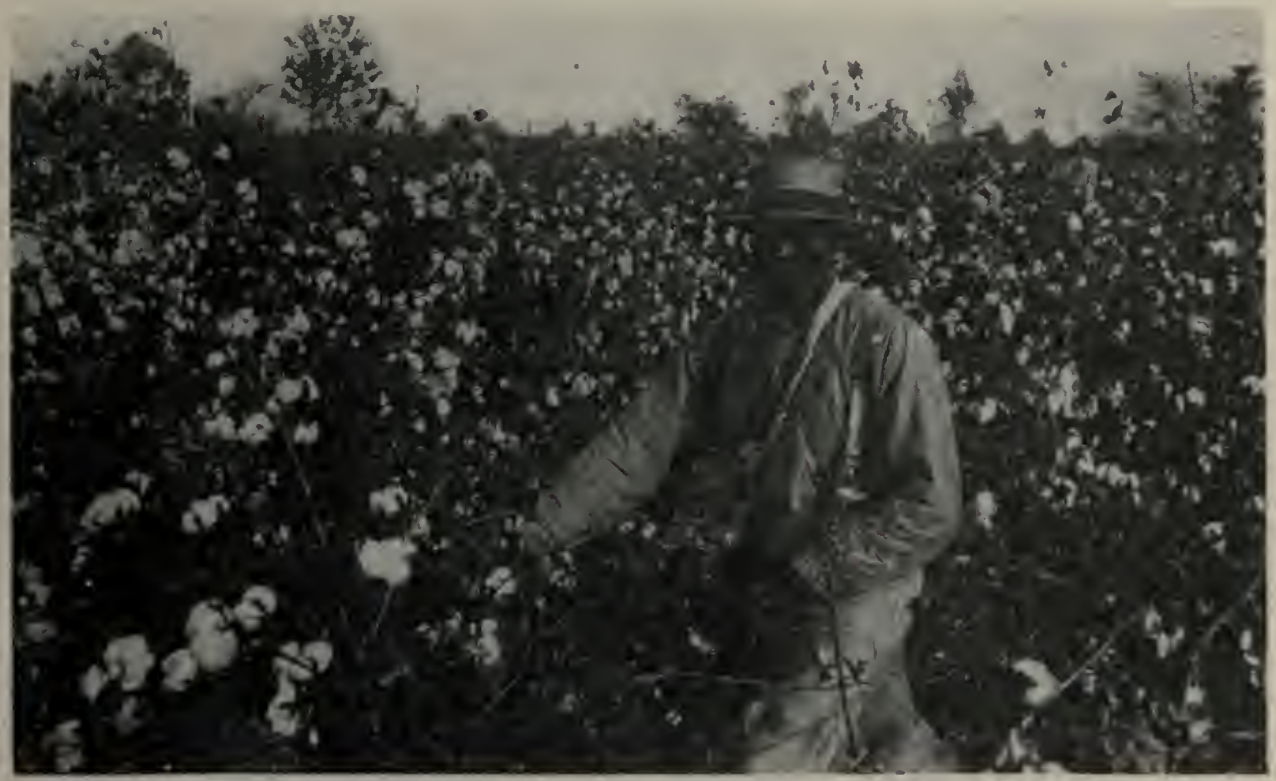

Cotton, the Principal Money Crop

\section{Cotton}

In common with the other Southern States, Louisiana has a large territory adapted to this plant, but Louisiana has the added advantage of any other southern state in that a larger percentage of her territory is eminently adapted to the production of sugar-cane and rice; and of late years, especially since the appearance of the boll weevil, these crops, with corn, have proven safer and more profitable than cotton upon the rich alluvial lands in the southern part of the State. But from the northern part of the State, south to the Atakapas Prairies, cotton is the dominating crop, except on the alluvial lands south of the mouth of the Red River. North of this river, even on the alluvial lands, cotton replaces sugar-cane and becomes the principal crop. In the Pine Hill Lands, where there is much cut-over land, cotton produces a good yield with a small amount of acid phosphate as a fertilizer. The yield is from one-fourth of a bale on lands in the northern part of the State, to one-half or threefourths of a bale on the uplands and Atakapas Prairies, to a bale or one and one-half bales on the rich Alluvial and Reclaimed Marsh Lands. 


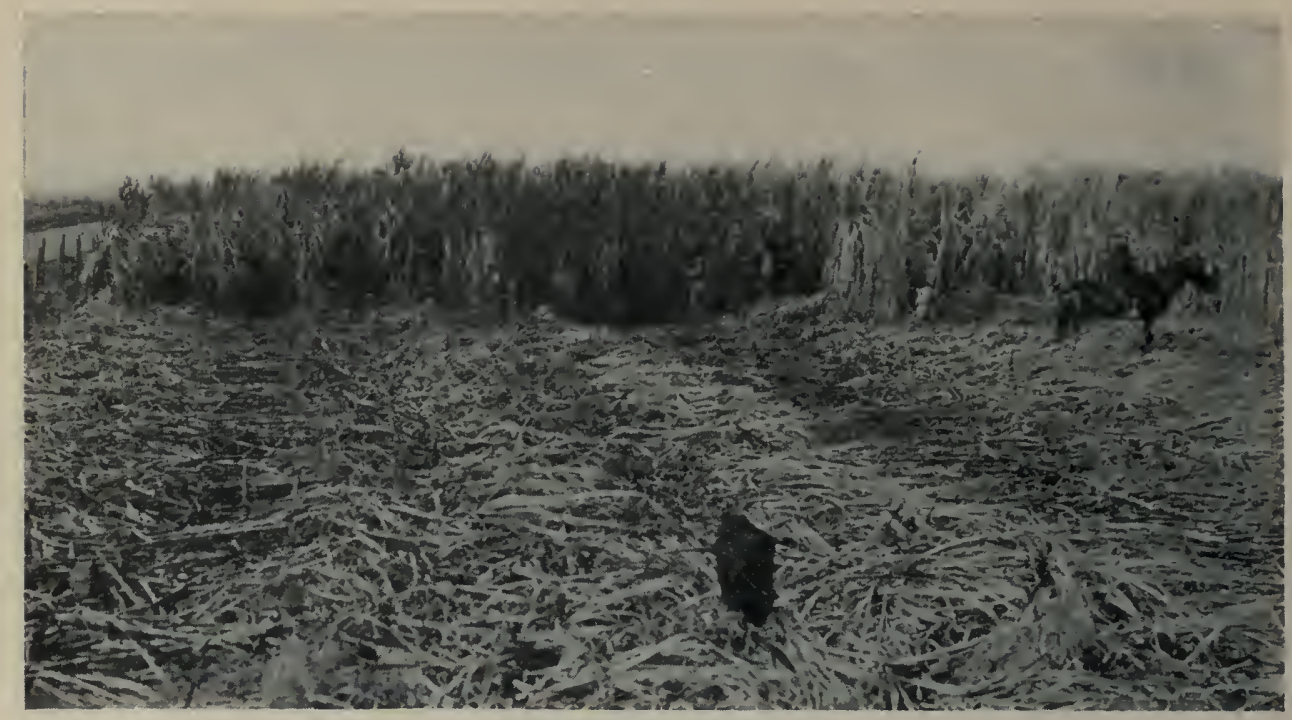

Cutting Sugar-Cane

\section{Sugar-Cane}

The mention of this crop is almost synonymous with a mention of the State. Louisiana is the only State in the Union where sugar-cane is grown in any considerable quantity for the production of sugar. Previous to the development of the beet sugar industry in this country, Louisiana produced practically all the sugar that was not imported. It stands second in value of the crops of the State. It is grown for commercial sugar only upon the rich Alluvial and Reclaimed Marsh Lands.

Sugar-cane requires a very rich soil and plenty of water, but it demands good drainage also. Its cultivation at the present time is confined principally to the large plantations from the mouth of the Red River south, although many farmers are raising sugar-cane on a small acreage and selling it direct to the mills on these plantations at prices ranging from $\$ 3.50$ to $\$ 8.00$ per ton. Approximately three-fourths of the cane crop of the State in the sugar mill district is produced by the mill owners; the remainder is purchased from tenant farmers of small areas and planters who do not own or share in the ownership of a mill factory.

In addition to the growth of sugar-cane in Louisiana for the production of sugar, a considerable acreage is grown for the production of cane syrup. Most of the sugar-cane raised for this purpose is produced by the small farmer and on the thinner, lighter lands of the State. It is an important fact also that cane for the manufacture of syrup can be grown much farther north than it can for the manufacture of sugar. The yield per acre is from 200 to 400 gallons and it is sold at prices ranging from ninety cents to $\$ 1.25$ per gallon at the present time, with an active demand. The crop is particularly adapted to the Pine Flats, when properly drained, to the Pine Hill Lands and much of the Uplands of the State.

\section{Corn}

This crop will grow anywhere in the State that cotton will grow, and, in addition, thrive in many places where cotton will not produce successfully. The Alluvial Soils of the State, as well as the reclaimed Marsh Lands of the Delta, are pre-eminent "corn lands." Louisiana has only recently given attention to the production of corn, and the results achieved have been surprising. Not only has the yield per acre, under improved methods, been much higher than formerly, but surprising results have been shown in the quality of the corn. In the cane belt area of the State, cane is now commonly grown in rotation with corn. Cowpeas are put in with the corn during cultivation of the crop, usually with the last plowing, and thus the fertility of the land is steadily maintained for the cane crop. 


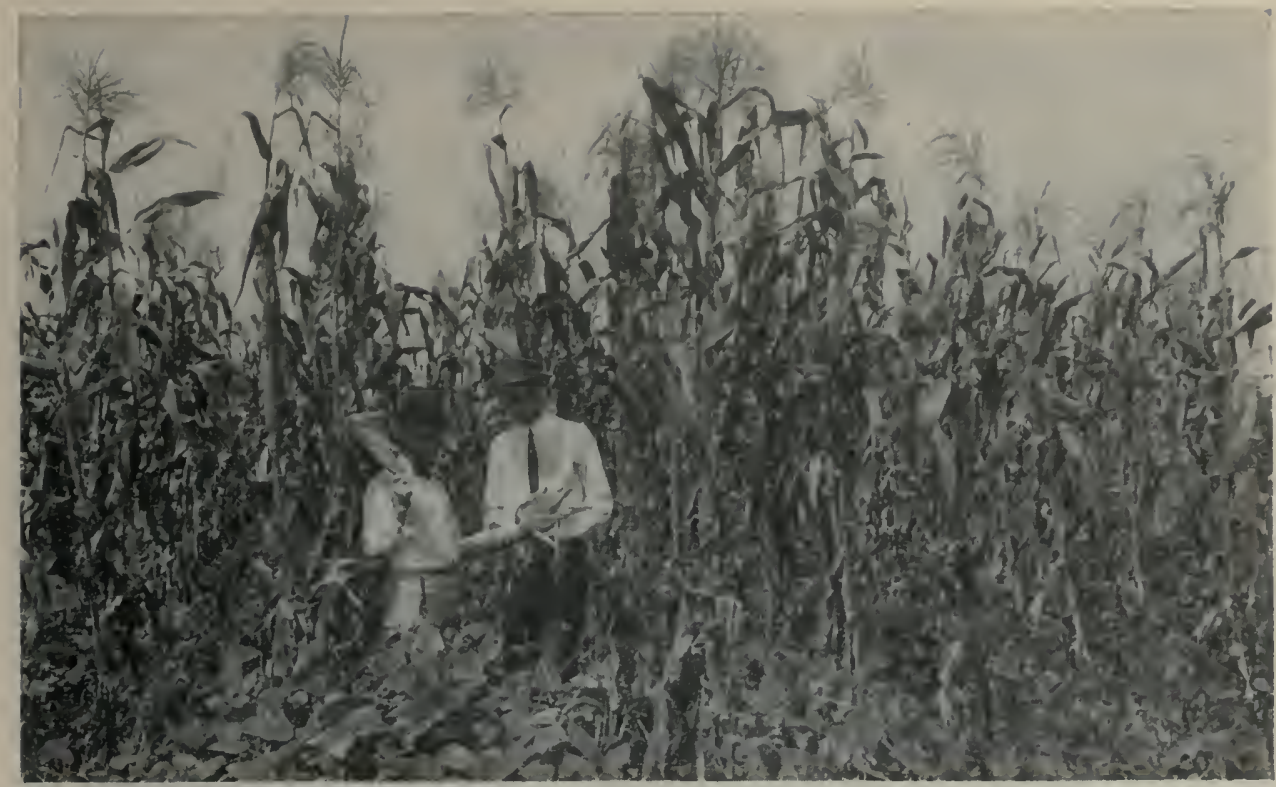

Field of Corn Yielding 250 Bushels on One Acre

Corn on the Alluvial Lands and the reclaimed Marsh Lands of the State yields from 50 to 100 bushels to the acre. This wide variation depends more upon the season than upon anything else; since a farmer usually plants all the acreage he can possibly take care of during a favorable season. If an unfavorable season comes, such as a late spring, deficient stand or too much rain, some crop must suffer; and with the southern farmer it is usually the corn.

Corn on the Bluff Lands and the Uplands is the principal crop next to cotton. These lands are commonly sufficiently fertile to produce profitable yields during favorable seasons of both cotton and corn without the use of fertilizers. By growing cowpeas, soy beans or velvet beans with the corn, however, for an increased nitrogen supply, the yield of both crops, especially of corn, may be materially and profitably increased, the yield being increased twenty-five to fifty bushels of corn to the acre.

It has been found that the moisture content of Louisiana corn is very low compared to that in corn produced in Illinois. For example, 13.4 per cent in Louisiana as an average against an average in Illinois corn of 19.1 per cent. This is due to the usual heat and dryness of the climate during August and September. This gives Louisiana an advantage in the early shipment of the crop that enables the buyer to get better corn.

\section{Rice}

Louisiana is as distinctively a rice producing State as she is a sugar producing State. The rice crop is an exceedingly important one to the State, not only because of the amount of capital involved in its production and the wealth evolved therefrom, but because by it lands in the State, dwhich were not well adapted to any other crop, have been utilized.

This crop is "confined almost entirely to the level alluvial lands of the Atakapas Prairies and to the Coast Marsh Lands of the southwestern part of the State. The acreage in 1918 was almost double that devoted to sugar-cane and distributed as follows: About 12 per cent of the acreage was in the River District, producing an average of 40.2 bushels to the acre; 6 per cent along the Teche, producing an average of 35.4 bushels to the acre; and 82 per cent in southwestern Louisiana, producing an average of 29.4 bushels to the acre. From this statement the relative productivity of the rice lands of the State can be discerned. The varieties of rice planted in percentage to the total acreage were, Honduras 12\%, Japan 5\%, Blue Rose 57\%, Louisiana Pearl 12\%, Early Prolific $10 \%$. Edith $2 \%$ and Carolina $2 \%$. 


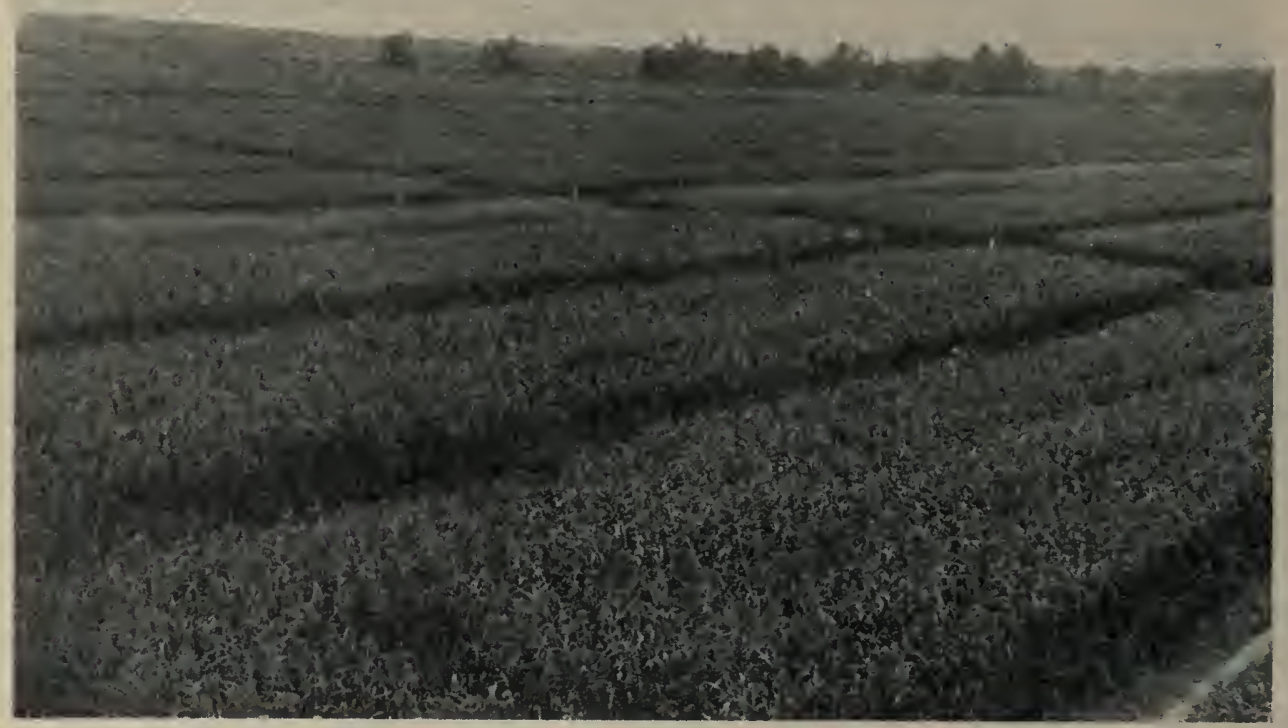

Louisiana, the Rice Granary of the United States

The rice plant is very sensitive to cold and must, therefore, not be planted too early in the season, and yet sufficiently early for it to mature before the cold nights of autumn come on.

Rice is not an expensive crop to grow compared to sugar-cane. 'The chief expense after planting is the cost of irrigation. The farm machinery required, however, and the teams demanded are somewhat expensive. For the last four or five years, the returns of the crop to the farmer have been highly satisfactory. The per acre yield of the State last season was thirty-one bushels and total production $17,980,000$, bushels with a valuation of $\$ 35,061,000$.

Rice polish and rice bran are important stock feeds. Mixed with other feeds to form a balanced ration, they are economic and highly nutritious for either dairy or beef cattle and for hogs.

\section{Hay}

The area of the cultivated or tamed varieties of hay was, for the year 1918, 200,000 acres. Wild hay occupied about 38,000 acres. The yield of the cultivated hay amounted to 1.3 tons per acre, against a ten-year average production of 1.6 tons. The yield for wild hay per acre was one ton against a ten-year average production of 1.3 tons. Usually about 45 per cent of the hay crop is baled.

Hay meadows and pastures will, of course, thrive well in any part of the State. The soil, the rainfall and the mild winters afford almost an ideal condition for the growth of grasses. The better the soil, of course, the more luxuriant the crop. For this reason the alluvial lands are the best hay lands, but these lands are so completely utilized for other crops that they have not, as a rule, been devoted to hay crops.

\section{Alfalfa}

Alfalfa does particularly well on the rich alluvial lands of the State, when these are properly drained, and will also thrive well on the Atakapas Prairies, when these are properly drained and sufficiently limed. It can be grown with a reasonable degree of success on the Bluff Lands of the State, when properly fertilized and sufficient quantities of lime applied.

The acreage increase of alfalfa in 1918 over the preceding year was ten per cent. The yield per acre (all cuttings) was 2.2 tons and the production in round numbers 55,000 tons. 


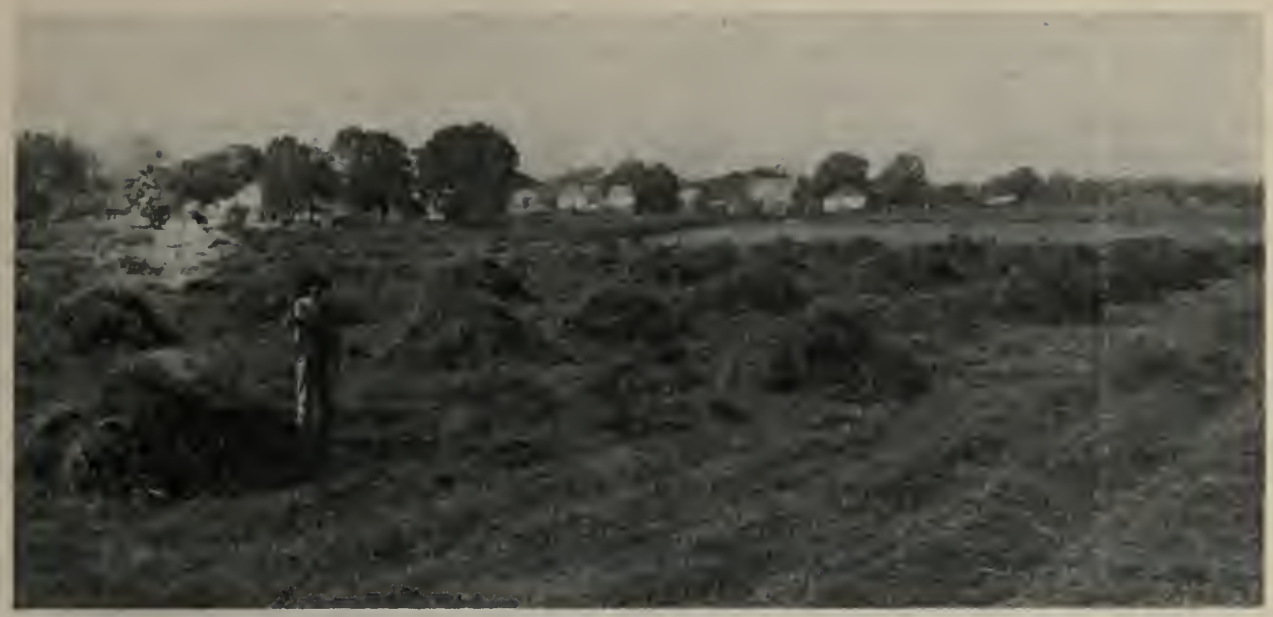

Lespedeza, One of the Best Hay Crops-31/2 Tons per Acre

\section{Lespedeza}

Any notice of the agricultural resources of Louisiana and opportunities in the State would be incomplete without mention of lespedeza, or Japan clover, used both for pasturage and as a hay crop.

On thin land it does not attain sufficient height to cut for hay, but on the fertile lands it commonly grows from twelve to fifteen inches high, and sometimes even higher. It demands plenty of moisture and does well on soil with good surface drainage. It thrives on a great variety of soils, and where the proper conditions of soil and climate are present, it will grow in timbered lands; thus adapting itself to shady woodlands or to sunny fields. In Louisiana it seems to do best upon the Bluff Lands and the Alluvial Lands of the Mississippi, Ouachita and outlying bayous. The plant is an annual, but will re-seed itself and thrive in the same soil from year to ycar. Lespedeza hay is very nutritious, comparing favorably with alfalfa, and is much easier cured than alfalfa hay, but does not yield as heavily. It is a valuable soil renovator and these three-fold utilities of the plant-as a hay, for pasturage and for the improvement of thin soils-make it of great economic value to the State.

\section{Velvet Beans}

No other crop which can be grown in the field with the corn crop will so rapidly increase the fertility of the soil as velvet beans. The crop is not used ordinarily for hay, but grown as a soil renovator and then pastured. After the

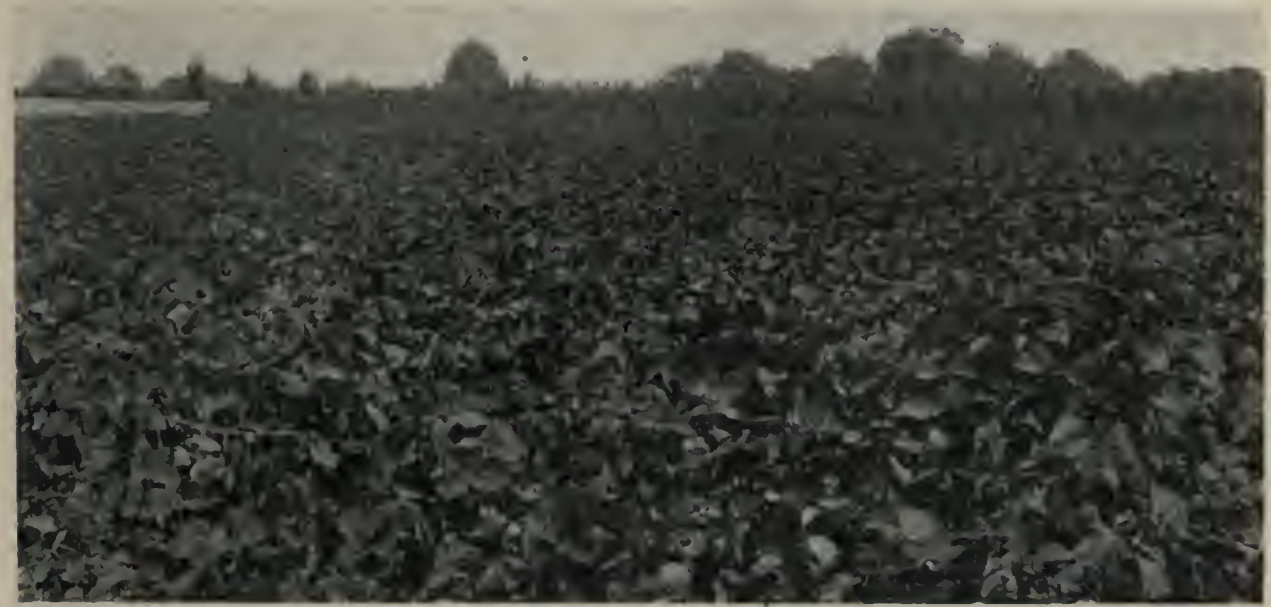

Velvet Beans-a Soil Improver 
first frost, the beans may be gathered, crushed and marketed as velvet bean meal, but it is more profitable to pasture the field with cattle and hogs.

Velvet beans, in connection with live-stock raising, give an increased value to the thinner soils of the State, but the intrinsic value of these soils, because of the productivity and value of certain crops produced upon them, is only beginning to be appreciated.

\section{Oats}

Upon the Bluff Lands of northeastern Louisiana and upon the Alluvial and Uplands of the northern part of the State, oats yield a valuable crop. This crop is of great agricultural value for winter grazing, to be utilized later either for hay or for grain. Oats and hairy vetch, or oats and lespedeza are sometimes sown together with profit. They can be grazed during the winter and produce valuable hay when cut successively in the spring and summer.

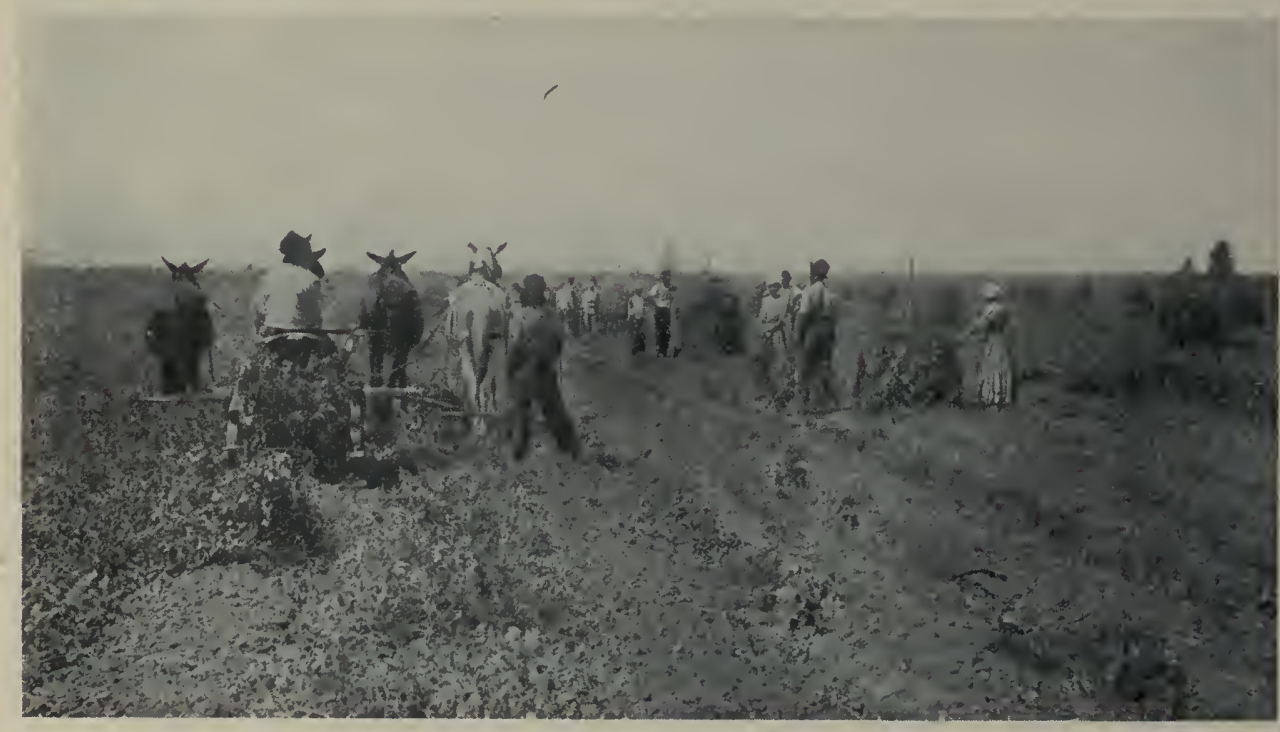

Harvesting Peanuts

\section{Peanuts}

Peanuts can be grown very successfully in Louisiana and utilized in various ways. They can be fed to the live stock on the farm with great profit, either to the farm work stock, milk cows, fattening beeves, and especially to hogs, which can be turned in the field and allowed to do their own harvesting. The entire plant, that is the top and nuts, form practically a balanced and highly nutritious ration for live stock. The tops themselves are equal to alfalfa as a hay.

- This crop, together with the sweet potato crop and sugar-cane crop for syrup, makes possible the economic utilization of the Pine Hill Lands of the State and the thinner soils of the Uplands to an extent only second in value in farm opportunities to the richer soils of the State. The yield of peanuts on the thinner soils of the State, without fertilizer and without being limed, will average about thirty-five bushels to the acre and half a ton of tops to the acre. The nuts should be worth about $\$ 1.25$ a bushel and the hay from the tops about $\$ 25.00$ to $\$ 30.00$ a ton.

\section{Sweet Potatoes}

Sweet potatoes and peanuts demand essentially the same type of soil, either a sandy or sandy loam, except that sweet potatoes require considerably more moisture for best results than peanuts. For the sweet potato crop there is such a thing as the land being too rich, in which case more vines than potatoes will be produced.

Within recent years the construction of sweet potato curing houses, where the tuber is deprived of its excess of water, has given an increased value 
to the crop, and a renewed interest in its production. By means of these curing houses, it is possible to distribute the crop to the market throughout the winter and spring months in such a way as to protect the price and facilitate the consumption.

The yield per acre will vary from 150 to 400 bushels and the price to the farmer during the last season varied from $\$ 1.00$ to $\$ 1.75$ a bushel, according to whether the crop was thrown on the market immediately after digging, or put in the sweet potato curing house and sold later in the season after the supply diminished and the market advanced.

Sweet potatoes are a valuable stock feed, but being excessively high in starch and sugar, they, of course, need to be balanced with some protein food for best results. Their market value, however, for human food precludes their ordinary use for live stock. The sweet potato crop very commonly follows the Irish potato crop upon the same land.

\section{Truck Crops}

The mild climate of Louisiana, especially the country adjacent to New Orleans, with an exceedingly rich soil and abundant rainfall, is particularly suited to the production of winter truck crops. For more than a century, in fact, New Orleans has been the center of an intensive system of truck farming. The Reclaimed Marsh Lands and the Alluvial Lands, with proper drainage, are ideal soils for the truck farmer.

Cabbage, cauliflower, brussels sprouts, kohlrabi, kale, mustard, parsley, spinach, turnips, radishes, beets, carrots, onions, garlic, etc., may be grown through the winter months. Two crops a year, one in the spring and one in the fall, may be grown of snap beans, tomatoes, sweet peppers, eggplant, English peas, Irish potatoes, sweet corn, etc.

The trucking industry, however, is not confined to the environments of the Crescent City, nor to the rich Alluvial and Delta Lands of the State. The commercial production of tomatoes, spring Irish potatoes, cabbage and strawberries extends well over the State in its varying soil divisions. The vegetable crop for the entire State, for 1918, exclusive of the Irish potato crop and the strawberry crop, amounted to $\$ 3,100,000$.

The Bluff Lands, the Uplands, the Pine Hill Lands and the Pine Flats, when properly fertilized, are admirably adapted to the production of truck crops. The profits to the truck grower, or market gardener, in Louisiana are always attractive. Vegetable shipments to be remunerative must be brought on the market at a time when they will not be forced to compete with vegetables grown in the zone to the north of them.

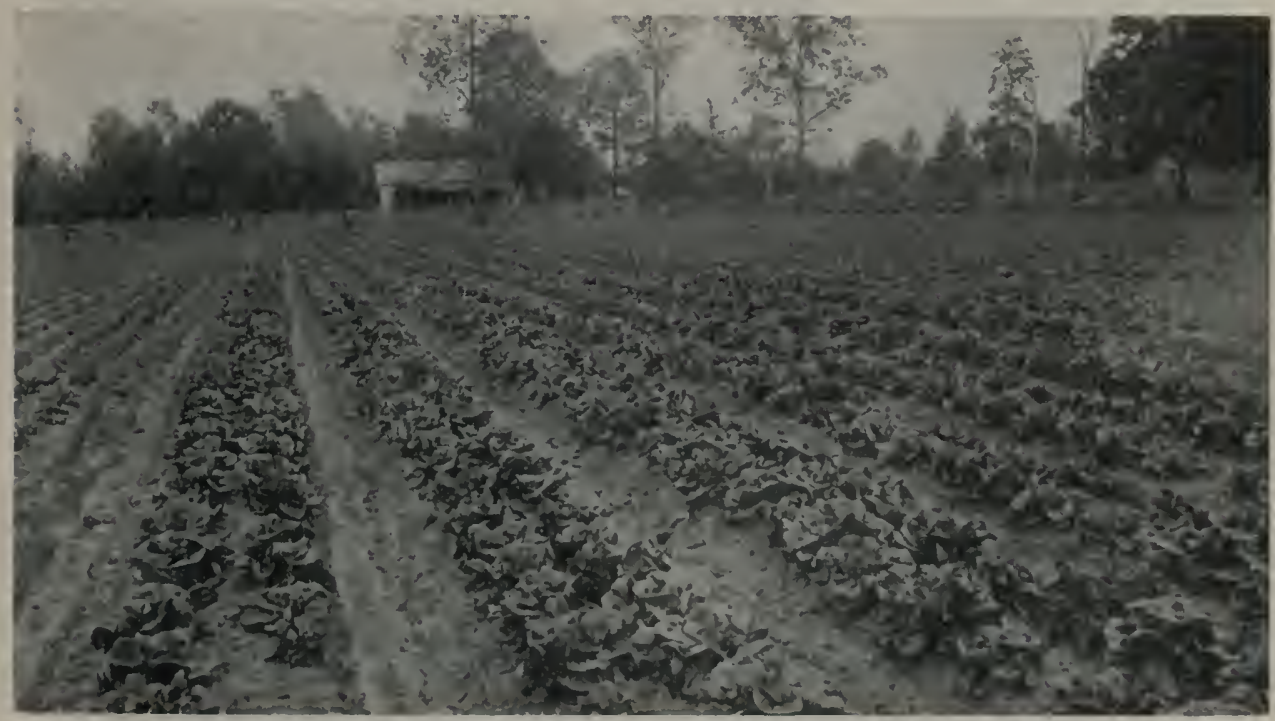

Head_Lettuce of the:Finest Quality Grownlon Cut-Over Pine LandsReady for Shipment in_February 


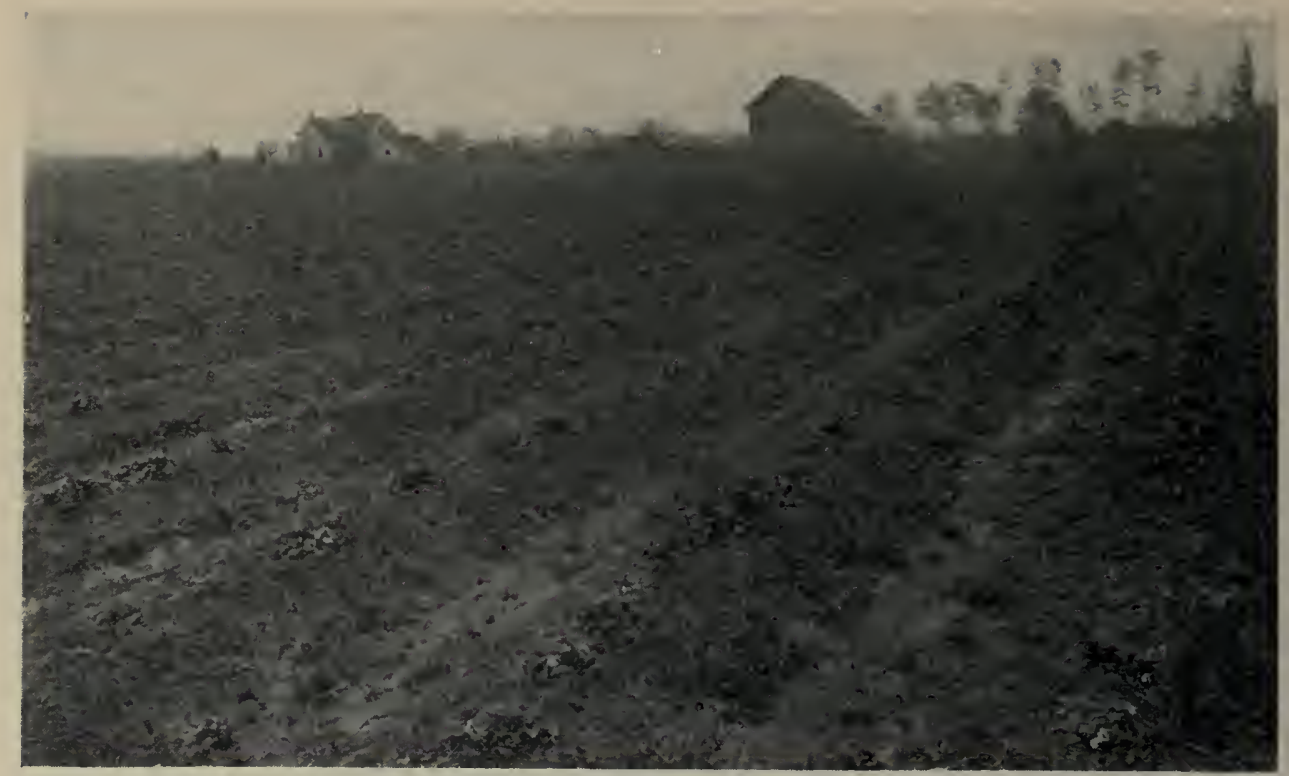

Strawberries-a Million-Dollar Crop

\section{Strawberries}

Commencing about February 25 th and continuing through the berry season, tourists and travelers will be greeted at every railroad station in the Pinywoods Strawberry Section by the cry of "Strawberries!" "Strawberries!" "Strawberries!" as the small boy cries his wares to the traveling public. This sight is just as familiar as the city newsboy selling the morning paper.

The principal strawberry section is that territory east of the Mississippi and north of Lake Pontchartrain, from which more than two million dollars' worth of berries is shipped annually. These berries have a celebrated reputation for quality and flavor and the "Louisiana Strawberry" has become a household name with the northern housewife.

The Louisiana berry finds a ready market in all the larger cities of the North, carried by fast freight trains in refrigerator cars, arriving in Chicago the third morning, and if shipped by express, the berries are on South Water Street the second morning.

Fabulous returns have been made by the strawberry and truck grower in this section. The capacity of the soil to produce under intensive cultivation has not been thoroughly tested. It is not unusual for an acre to produce from 300 to 400 crates of strawberries, which gives the farmer a net average return of $\$ 3.25$ per crate, or $\$ 975$ to $\$ 1,300$ per acre.

Twenty acres under intensive methods of cultivation means a home and independence for the man of small means.

\section{Citrus Fruit}

Along the Gulf Coast of Louisiana on both banks of the Mississippi River below New Orleans, exceptional opportunities are offered for citrus fruit growing. The great fertility of the soil, the mild temperature and the abundant rainfall, with excellent market facilities, mark this region as a distinctive citrus fruit belt and should be held in much higher appreciation. Nothing but a lack of knowledge of the opportunities it has, prevents the country from being further advanced in its development. The naval orange produced in this section is without doubt the kest orange grown in the United States. The Louisiana sweets and the tangerine grown in this territory are famous for their fine quality and are in high demand. Grapefruit finds here conditions suitable for its greatest production, and the extension of orchards will undoubtedly take place very rapidly. 


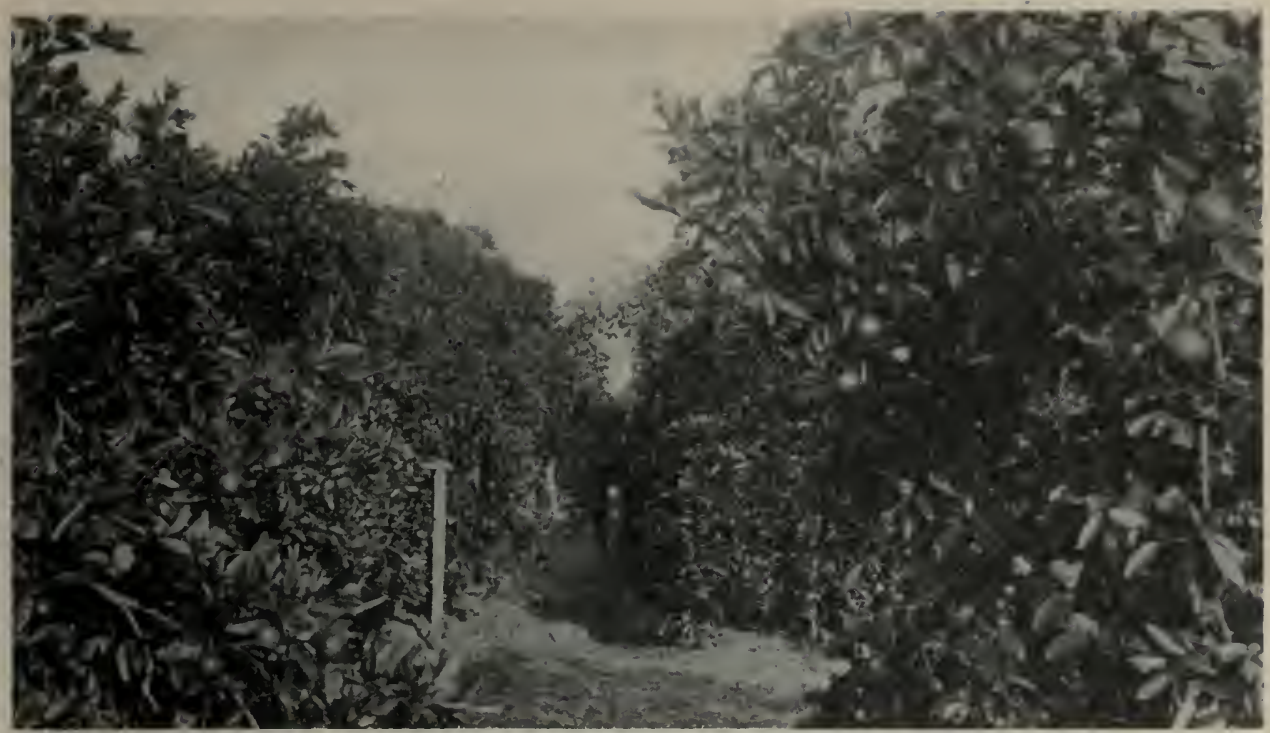

Louisiana Oranges Aro Unequaled

The New Orleans market has eagerly consumed the entire output of this Louisiana citrus belt, and for that reason the superior quality of the product is not generally known in other parts of the country, but as new orchards come into bearing, the quality and flavor of the Louisiana oranges, the grapefruit and the tangerine will undoubtedly attract the attention of the settler in search of a milder winter, where he may pick the fruit from his own tree through the season and grow profitable summer crops in addition.

\section{RAINFALL AND CLIMATE}

According to figures furnished by the United States Department of Agriculture Weather Bureau, the normal monthly and annual temperature and precipitation for the State of Louisiana for the year 1918 were as follows:

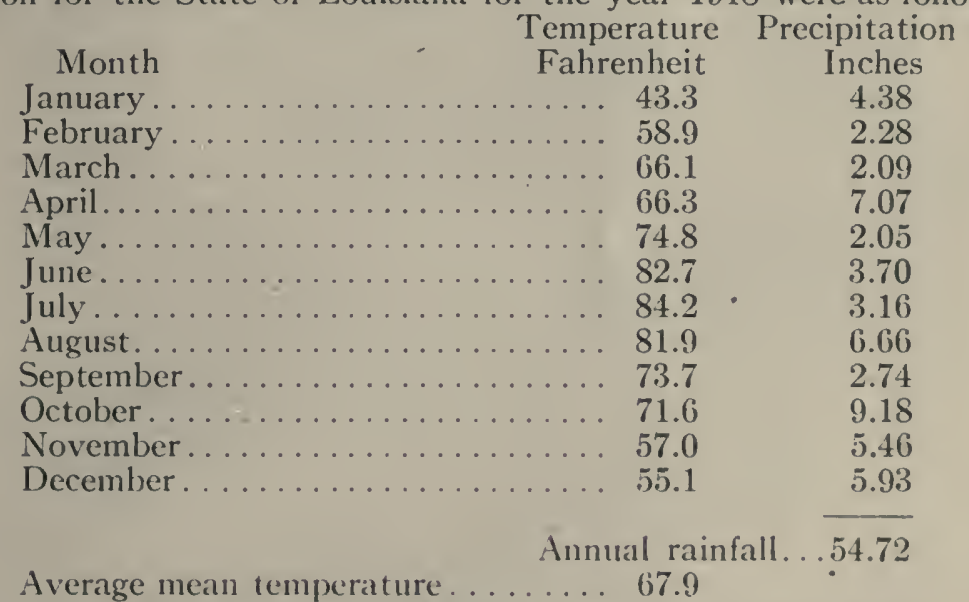

Average monthly rainfall 4.56

\section{HEALTH AND LIVING CONDITIONS}

The intelligent homeseeker, in considering a change of location, is likely to be influenced by the following conditions:

First: Health conditions.

Second: Educational advantages.

Third: Opportunities for bettering his financial or economic condition.

There is conclusive evidence on record that the State of Louisiana is a healthful region in which to live and which completely refutes the misrepresentations 


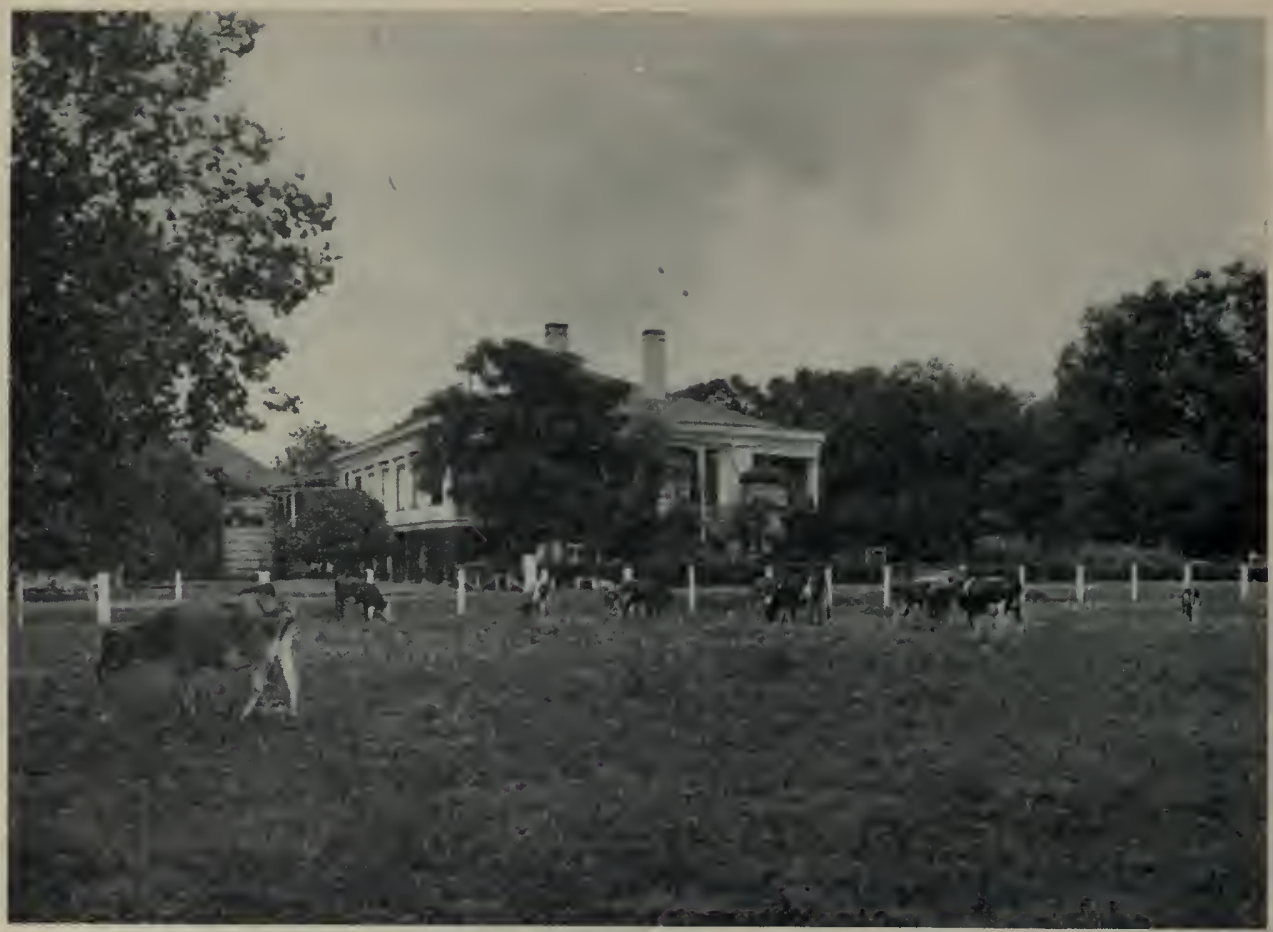

Far Removed from Winter Snows, in a Land of Pleasure and Plenty

of the past. The mortality rate for 1917 per 1000 was 12.5 -a very low rate as compared with other states.

Louisiana has an ideal climate. Outdoor work is never retarded because of too much cold or too hot weather, and heat prostrations or sunstrokes seldom, if ever, occur. Purer water can be found nowhere than that flowing from the artesian wells in every portion of the State, an analysis of which shows it to be of the very best quality.

Dr. Oscar Dowling, President Louisiana State Board of Health, says:

"From personal observations as State Health Officer throughout eight years, I do not hesitate to say that conditions in Louisiana are almost ideal, both as to climate and health, provided the people live in accordance with the ordinary rules of hygiene. The homeseeker will make no mistake in coming to Louisiana to live. I would not be understood to claim that sanitary or health conditions throughout the South are all that could be desired, nor could I say the same concerning the North or any foreign country, but I do mean to say that, with its salubrious climate, one may settle in any of our Southern States and by observing, for himself and his family, the sanitary laws and principles now so well understood, he will be under as favorable conditions for health and length of life as he could be anywhere."

With climatic and living conditions almost ideal; with educational facilities second to none; with natural magnificent resources and a most fertile soil, we know of no territory better qualified for bettering the financial and economic condition of the homeseeker than the State of Louisiana.

\section{EDUCATIONAL FACILITIES}

Louisiana now has 300 four-year State approved high schools located in all parts of the State; she has numerous junior high schools, and in the development of her country schools she has made phenomenal strides during the past few years. Hundreds of consolidated schools offering industrial and high school courses have been organized, thus insuring the country boy and girl equal educational advantages accorded the boys and girls of the towns and 


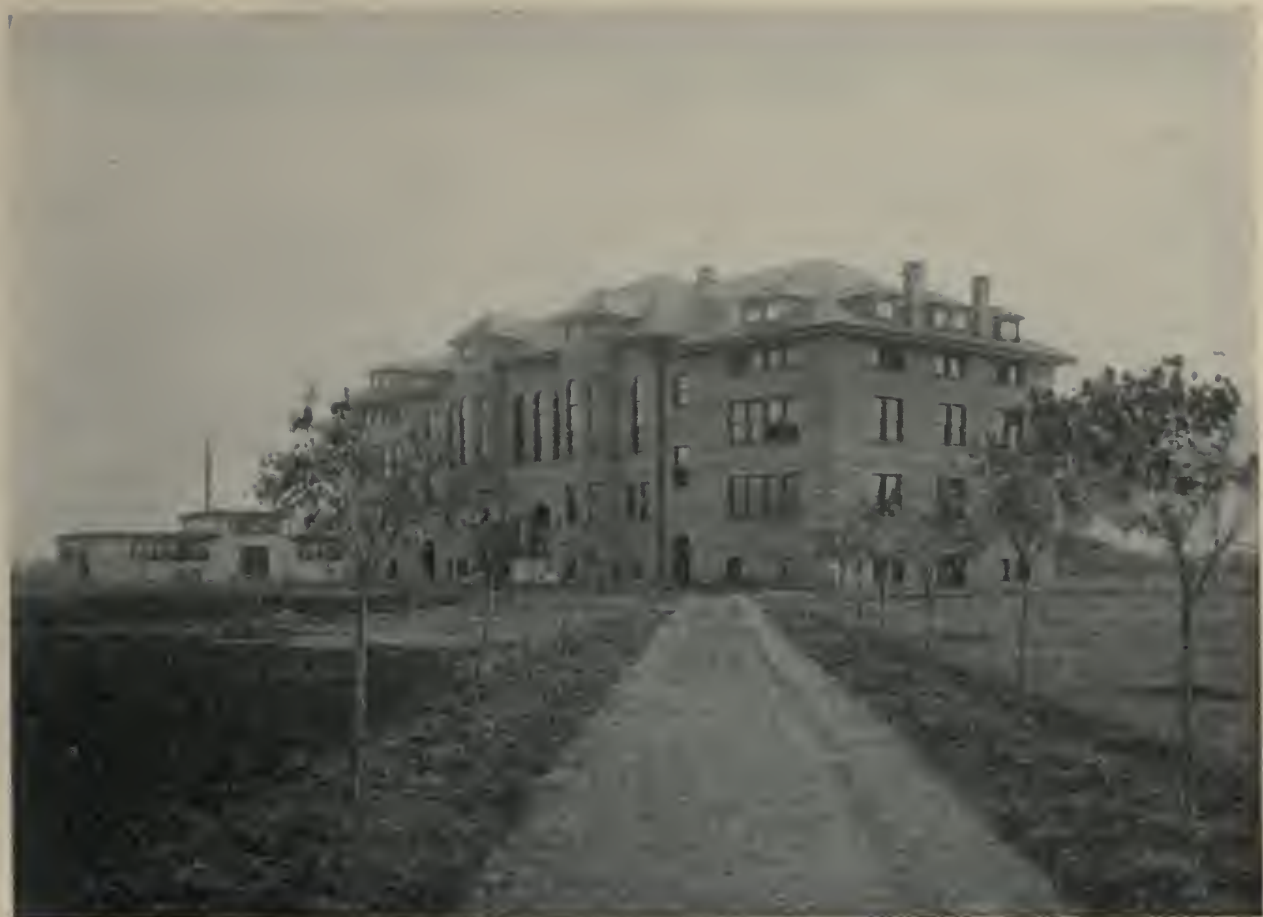

Louisiana Affords Splendid Educational Facilities

cities. The State has recently (November 5, 1918) adopted constitutional amendments which guarantee adequate revenues for the proper education of all children within her gates.

The educational facilities of the State consist of the following:

\section{School Systems}

(a) State System of Public Schools, supported by taxation and appropriations; supervised by State Superintendent of Public Instruction, a State Board of Education and Parish School Boards.

(b) The City School Systems, the same as exists in other states.

\section{Higher Education}

(a) Accredited high schools pursuing course of study approved by State Board of Education.

(b) The State University and Agricultural and Mechanical College.

(c) Tulane University of Louisiana, located in New Orleans.

\section{Professional Educational Training}

(a) State Normal School at Natchitoches.

(b) New Orleans Normal School.

(c) State Teachers' Institutes and Summer Normal Schools.

(d) Parish 'Teachers' Institutes of one week duration.

(e) Educational Associations.

\section{Industrial Education}

(a) The State Industrial Institute at Ruston.

(b) The Southwestern Industrial Institute at Lafayette.

\section{Education of the Colored}

(a) Public schools in cvery town, city and parish.

(b) Southern University for the higher and industrial training of the negro youth.

Too much cannot be said concerning the splendid work being done by the Louisiana State University and Agricultural and Mechanical College, and the Extension Department in the greater agricultural development of the State. 


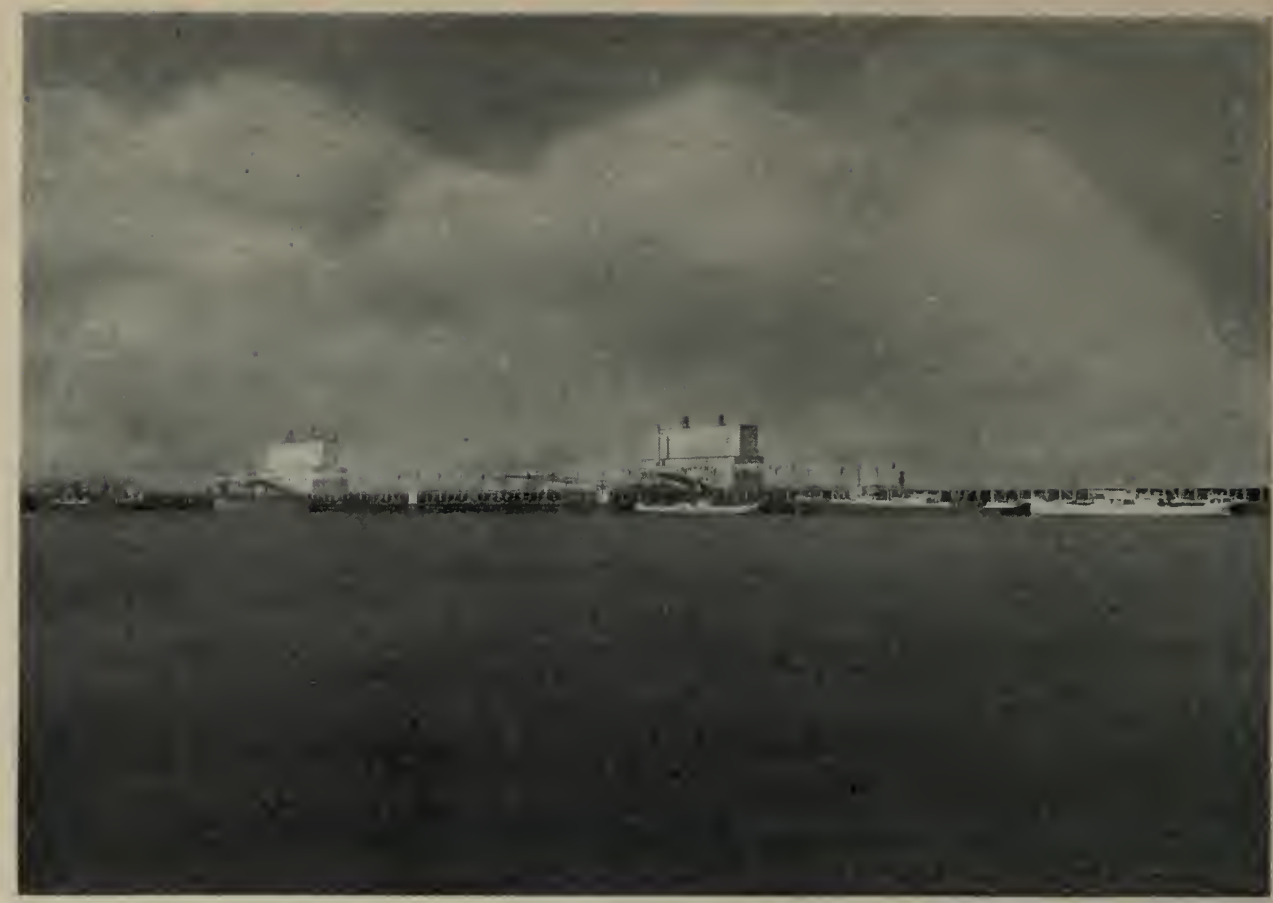

Grain Elevators at the Port of New Orleans for Export Trade Have a Capacity of 7,122,000 Bushels

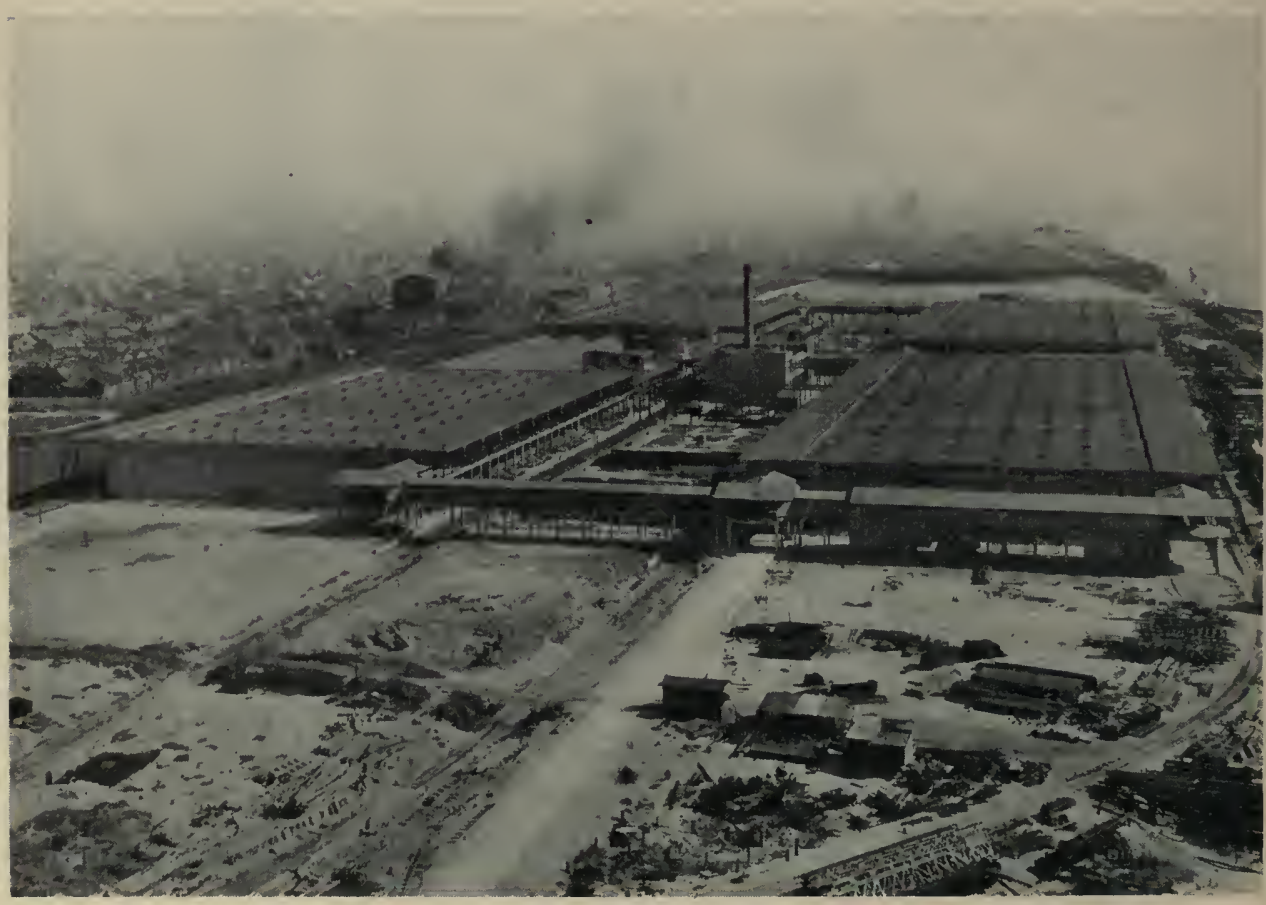

Port of New Orleans, the Gateway to the Mississippi Valley Trado, both for Import and Export. Cotton Warehouse in the Foreground, the Largest of Its Kind in the World 


\section{Issued by}

UNITED STATES RAILROAD ADMINISTRATION

AGRICULTURAL SECTION

J. L. EDWARDS, Manager

WASHINGTON, D. C.

For Further Information Address 

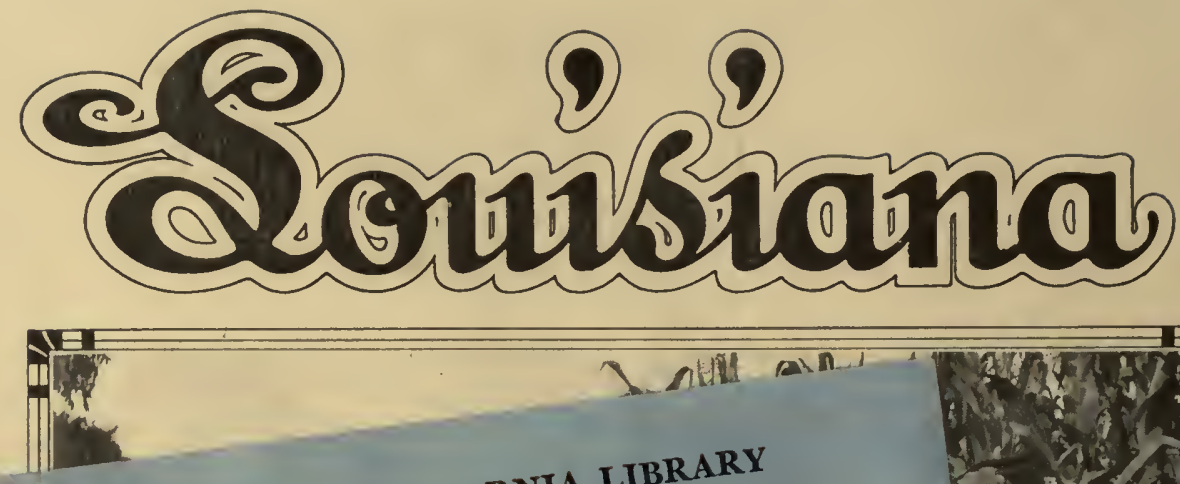

UNIVERSITY OF CALIFOR
BERKELEY

Return to desk from which borrowed.
DUE on the last date stamped below.

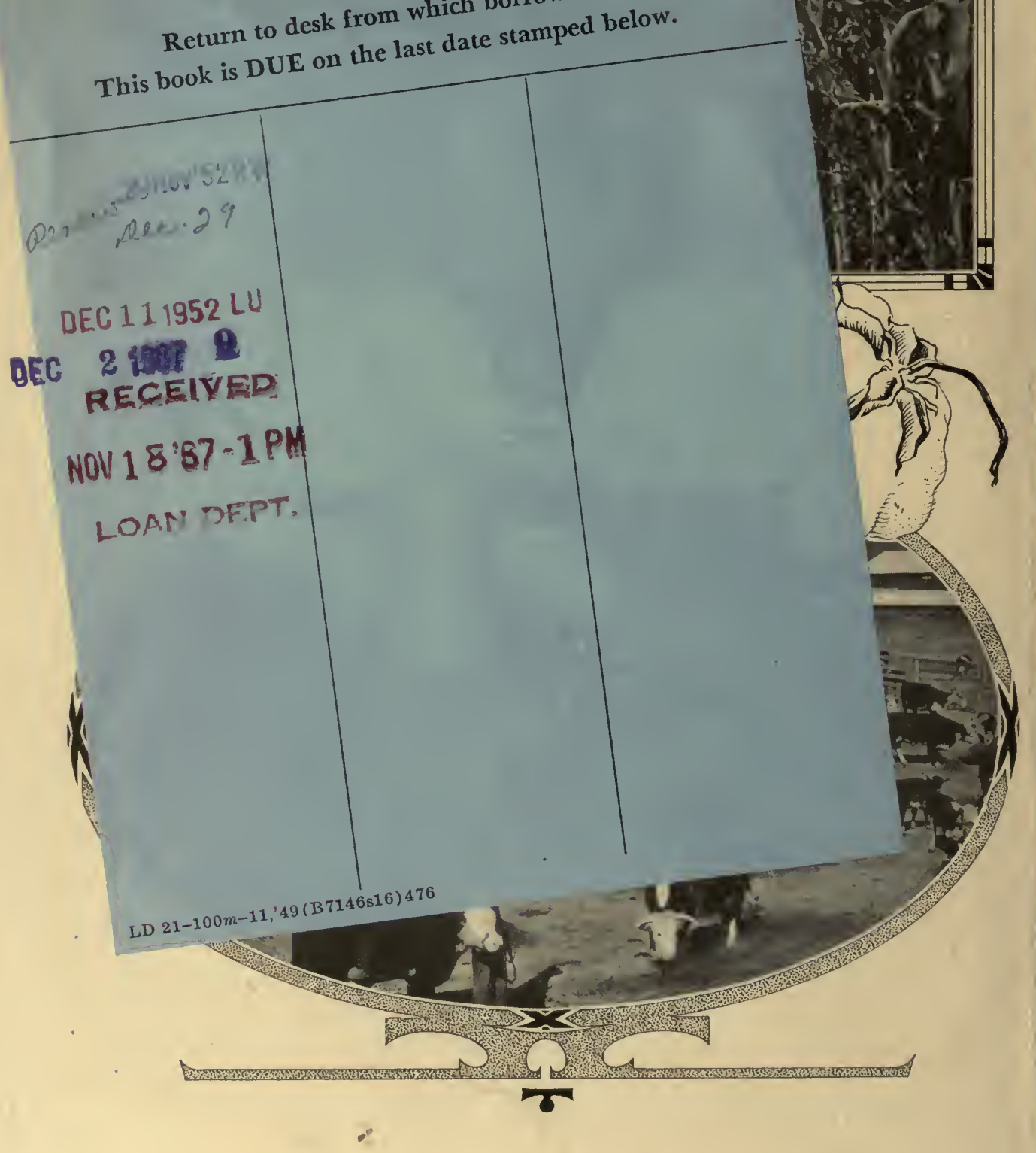




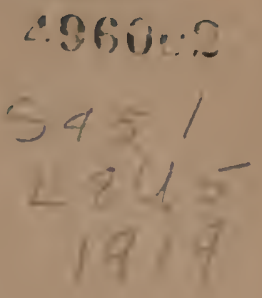

UNIVERSITY OF CALIFORNIA LIBRARY 
